\title{
Uncoupling proteins: functional characteristics and role in the pathogenesis of obesity and Type II diabetes
}

\author{
L. T. Dalgaard, O. Pedersen \\ Steno Diabetes Center, Gentofte, Denmark
}

\begin{abstract}
Uncoupling proteins are mitochondrial carrier proteins which are able to dissipate the proton gradient of the inner mitochondrial membrane. This uncoupling process reduces the amount of ATP generated through an oxidation of fuels. The hypothesis that uncoupling proteins (UCPs) are candidate genes for human obesity or Type II (non-insulin-dependent) diabetes mellitus is based on the finding that a chemical uncoupling of the mitochondrial membrane reduces body adiposity, and that lower metabolic rates predict weight gain. It is straightforward to hypothesize that common polymorphisms of $U C P 1, U C P 2$ and $U C P 3$ genes lower metabolic rate by a more efficient energy coupling in the mitochondria. Furthermore, genetically engineered mice over expressing different UCP homologues are lean and resistant to diet-induced
\end{abstract}

obesity. The three uncoupling protein homologue genes $U C P 1, U C P 2$, and $U C P 3$ have been investigated for polymorphisms and mutations and their impact on Type II diabetes mellitus, obesity, and body weight gain or BMI. The main conclusion is that variation in the $U C P 1, U C P 2$ or $U C P 3$ genes is not associated with major alterations of body weight gain. The contribution of $U C P$ genes towards polygenic obesity and Type II diabetes is evaluated and discussed. [Diabetologia (2001) 44: 946-965]

Keywords Uncoupling proteins, Type II diabetes mellitus, obesity, genetics, body weight regulation, energy expenditure, metabolic rate, brown adipose tissue, white adipose tissue, reactive oxygen species, polymorphism, mutation, transgenics, gene knockout.
An enormous amount of data has been collected on the uncoupling proteins 2 and $-3(\mathrm{UCP} 2$ and -3 ) since their discovery in 1997 and well over 400 publications with either UCP2 or UCP3 or both as a keyword currently exist in public bibliographic databases. This is

Received: 28 February 2001 and in revised form: 24 April 2001

Corresponding author: Oluf Pedersen, MD, DMSc, Steno Diabetes Center, Niels Steensens Vej 2, DK-2820 Gentofte, Denmark, E-mail: olufp@dadlnet.dk

Abbreviations: UCP, Uncoupling protein; RMR, resting metabolic rate; BMR, basal metabolic rate; BAT, brown adipose tissue: ROS, reactive oxygen species; BMCP1, brain mitochondrial carrier protein 1; WAT, white adipose tissue; skm, skeletal muscle; LPS, lipopolysaccharide; PPAR, peroxisome proliferator activated receptor; $24 \mathrm{~h}-\mathrm{EE}, 24$ hours energy expenditure; $\beta 3-\mathrm{AR}$, beta 3 adrenergic receptor; UTR, untranslated region; SMR, sleeping metabolic rate the equivalent of two new papers a week on the subject during the last four years, and that is excluding those papers on UCP1 alone. Despite the intense focus on these proteins their function and role in metabolism is not clear. There have been numerous clues to the possible functions of these proteins, and many theories have been offered but it is still not known what these uncoupling protein homologues actually do [1-6].

\section{Mitochondrial bioenergetics in brief}

The mitochondrial oxidation of substrates results in reduced $\mathrm{NADH}$ and $\mathrm{FADH}_{2}$, which deliver their electrons to the electron transport chain in the inner mitochondrial membrane. The chemiosmotic hypothesis proposes that oxidation is coupled by the elec- 
tron transport chain to the pumping of protons into the mitochondrial intramembrane space [7]. This creates a $\mathrm{pH}$-gradient (the proton motive force), and proton re-entry into the mitochondrial matrix is coupled to phosphorylation of ADP to ATP. Protons cannot enter the matrix through ATP synthase when ADP is not available. The steeper proton gradient in the absence of ADP inhibits the electron transport chain and the reduction of $\mathrm{NAD}^{+}$and FADH. As a result, substrate oxidation is closely coupled to energy needs.

However, mitochondria uses oxygen when ADP is not available (state 4 respiration), an indication that the coupling of substrate oxidation to ATP synthesis is imperfect. State 4 respiration is mostly due to uncoupling [8]. Uncoupling could, in theory, be due to proton leak (for example catalysed by an uncoupling protein) or to the slippage of the electron transport chain, so that it does not, for example, exclude a proton each time it transfers an electron.

\section{Proton leaks and variations in energy expenditure}

Proton leaks constitute a considerable part of the resting metabolic rate (RMR). An estimated $20-50 \%$ of total energy expenditure is due to proton leaks with skeletal muscle as the main contributor [9, 10]. Energy expenditure in humans can be divided into the basal energy expenditure measured under resting conditions, the energy expenditure caused by physical activity and the adaptive energy expenditure (including thermogenesis) observed in the metabolism of substrates. Variations in the resting metabolic rate are due to several determinants, including body composition (fat vs fat free mass), concentrations of thyroid and steroid hormones, genetics as well as the activity of the sympathetic nervous system [11]. Variations in energy expenditure could be a source of body weight variation in human beings [12, 13]. What evidence is there that energy expenditure is an inherited trait? Several studies have addressed this question by computing the intrafamilial correlations for basal metabolic rate or 24-h energy expenditure giving heritabilities of 0.26 to 0.70 [13-16]. It is clear that variations in energy expenditure between subjects have genetic determinants.

Low energy expenditure could predict future weight gain. In infants, children and adults, lower energy expenditure rather than increased energy intake has been reported to predict later weight gain [17-19]. However, other reports have thrown doubt on the predictive value of resting metabolic rate (RMR) for weight gain [20,21]. In one study, children of obese subjects had a lower RMR than the children of lean parents [22]. Only a slight imbalance between intake and expenditure (an estimated surplus of $\sim 0.3 \%$ ) is necessary for a weight gain if it persists over years [23]. Increasing the energy expenditure by increasing the proton conductance of mitochondria has long been recognised as an effective way to obtain weight loss. This has been achieved by intake of the chemical uncoupler dinitrophenol, which was used in the 1930's (for a review see [24]).

\section{The original uncoupling protein of brown fat: UCP1}

Brown adipose tissue (BAT) is a thermogenic organ, present in almost all mammals where it is a major site of cold-induced non-shivering thermogenesis as well as contributing to diet-induced thermogenesis [25]. BAT is a metabolically active tissue, which consists of adipocytes rich in mitochondria and small lipid droplets (Fig.1). This is in contrast to white adipose tissue (WAT), which contains large fat droplets and few mitochondria (Fig.1). In large mammals, such as humans, BAT is mainly active in infancy after which it largely disappears.

Thermogenesis in BAT is due to uncoupling protein 1 (UCP1). The special function of BAT has made the underlying molecular mechanisms an issue of great interest, and UCP1 (previously just UCP or thermogenin) was purified as early as 1978 [26]. The amino acid sequence was determined and its coding DNA sequence cloned in 1985 [27]. UCP1 is a dimeric protein present in the inner mitochondrial membrane (Fig. 2A), and it dissipates the $\mathrm{pH}$-gradient generated by oxidative phosphorylation, releasing chemical energy as heat. UCP1 is exclusively expressed in brown adipocytes, where the gene expression is increased by cold, adrenergic stimulation, $\beta_{3}$ agonists, retinoids and thyroid hormone [28] (Table 1).

UCP1 is activated by non-esterified fatty acids and inhibited by purine nucleotides [10]. Although coenzyme Q (ubiquinone) has been identified as a co-factor for the proton transport of UCP1 the mechanism by which UCP1 transports protons across the inner mitochondrial membrane is still to be determined [29, 30]. However, two models account for important facts concerning the kinetics and the regulation of UCP1 activity: the fatty acid protonophore (or flip-flop) model (Fig. 2B) [31] and the channel model (Fig. 2C) [32]. Both models predict a net transport of protons. The arguments for and against each mechanism have been reviewed elsewhere [10].

\section{UCP2 and UCP3: homologues to UCP1}

Uncoupling of the proton gradient of the mitochondria is thought to be important for energy dissipation as heat, maintenance of respiration, activation of substrate oxidation and prevention of reactive oxygen 
A

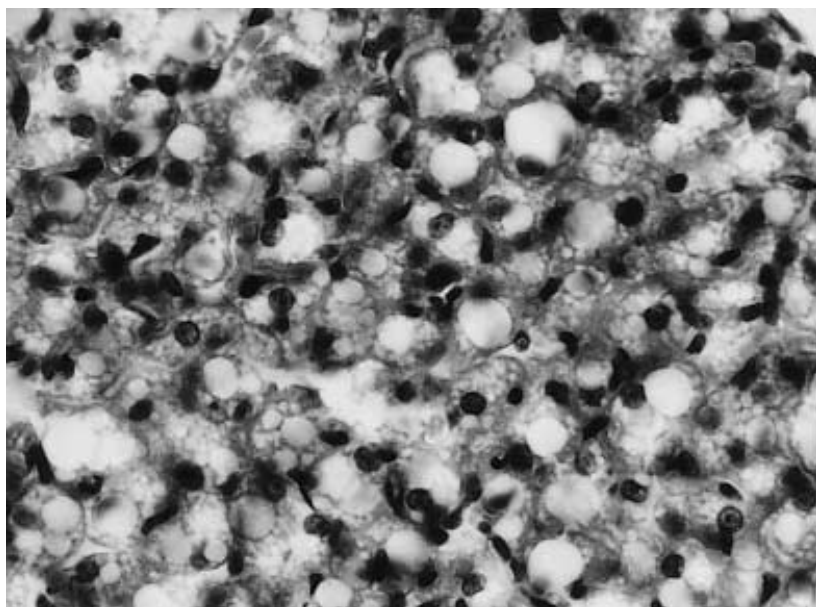

Fig.1. A Brown adipose tissue. The lipid droplets are small and plentiful and the nuclei are large and placed centrally (haematoxylin-eosin, magnification $\times 580$ ). B White adipose tissue. Cells contain one large lipid droplet and the nucleus is placed peripherally (haematoxylin-eosin, magnification $\times 295$ ). From Histology, Munksgaard, with permission

species (ROS - oxygen radicals) [33,34]. In newborn children and rodents, UCP1 is a major contributor to the energy expenditure, but since human adults contain very little BAT, the contribution of UCP1 to whole body energy expenditure is probably less. Substantial proton leaks in mitochondria from tissues not expressing UCP1 could indicate that other proteins catalyse the transport of protons. Several independent groups subsequently identified uncoupling protein 2 - and shortly after UCP3 (UCP2 and UCP3) [35-39]. Later other homologues were identified (UCP4, UCP5/BMCP1) [40, 41]. Although UCP4 and UCP5/BMCP1 share homology with UCP1, -2 and -3 , this homology is low ( $40 \%$ amino acid homology) and comparable to the homology shared between UCP2/UCP3 and other mitochondrial transporters.

In contrast to UCP4 and UCP5, human UCP2 and UCP3 are both more closely related to UCP1. The similarity of amino acid sequence between human $\mathrm{UCP} 2$ and UCP3 is $71 \%$ and the similarity to UCP1 is $55 \%$ and $57 \%$, respectively [38]. The genomic structures of human UCP2 and/or UCP3 were found to be similar to each other and to UCP1 (Fig.3) [42-45]. The human $U C P 3$ gene gives rise to two main, alternative transcripts due to a polyadenylation site in intron 6, which terminates approximately $50 \%$ of the transcripts. The first codon at the splice junction of exon 6/intron 6 is a stop codon. Therefore, human UCP3 exists as a long form called UCP3L and a short form called UCP3S. The latter lacks the last 37 C-terminal amino acids but is otherwise identical to UCP3L [44].

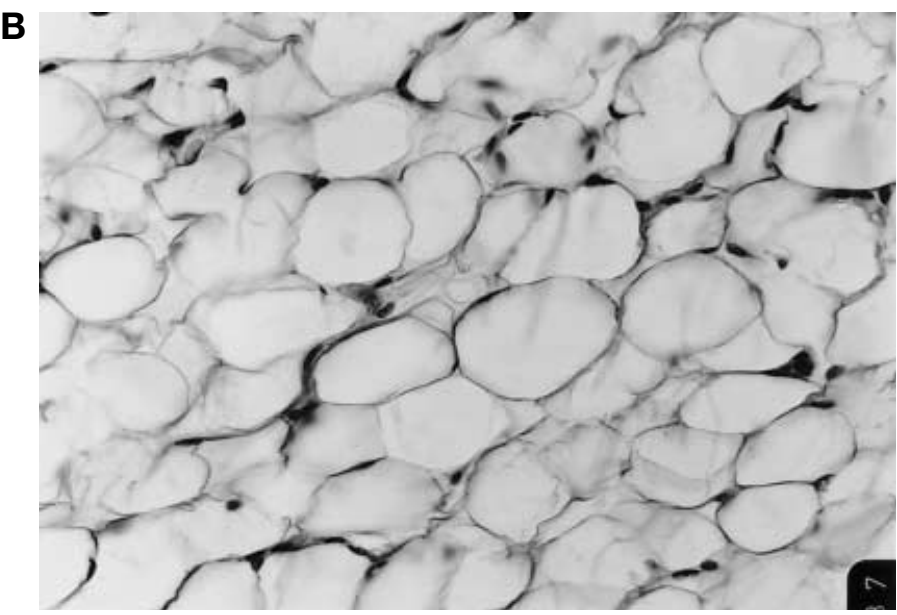

\section{Tissue distribution of UCP2 and UCP3}

UCP2 is expressed widely and in humans, high expression is seen in white adipose tissue. Other tissues (skeletal muscle, heart, placenta, liver, kidney, pancreas, brain, and cells of the immune system) express considerable amounts of UCP2 [35,36]. In mice, the tissue distribution of $U C P 2$ mRNA is even wider, with high expression also found in BAT, kidney, spleen and macrophages [35,36,46].

The tissue distribution of UCP3 is much narrower than UCP2. It is expressed, albeit abundantly, but only in skeletal muscle and brown adipocytes of humans and skeletal muscle and BAT of rodents $[37,38,47]$. This is interesting because of the important part skeletal muscle plays in the basal metabolic rate, which could, in part, be due to proton leaks caused by UCP3 and/or UCP2 [8].

\section{Possible functional roles of uncoupling protein homologues: do proton leaks increase energy expenditure or prevent reactive oxygen species?}

The precise role of the uncoupling protein homologues is not known but the body could have an energy-wasting system, inducible at times of positive energy balance, which could be composed of uncoupling protein homologues. Alternatively, the primary function of uncoupling protein homologues could be to act as inducible energy wasters. The energywasting process could also be a regulated means of thermogenesis in fever and inflammation [46, 48, 49].

A possible side effect of proton leaks is a higher flow rate through the electron-transport chain, and therefore a decrease in the half-life of radical intermediates such as the semi-quinone radical, which can donate its electron to oxygen and create reactive oxygen species (ROS). An uncoupling of oxidative phosphorylation to prevent free radical production when energy needs are low and ADP is not available 
A Intramembrane space
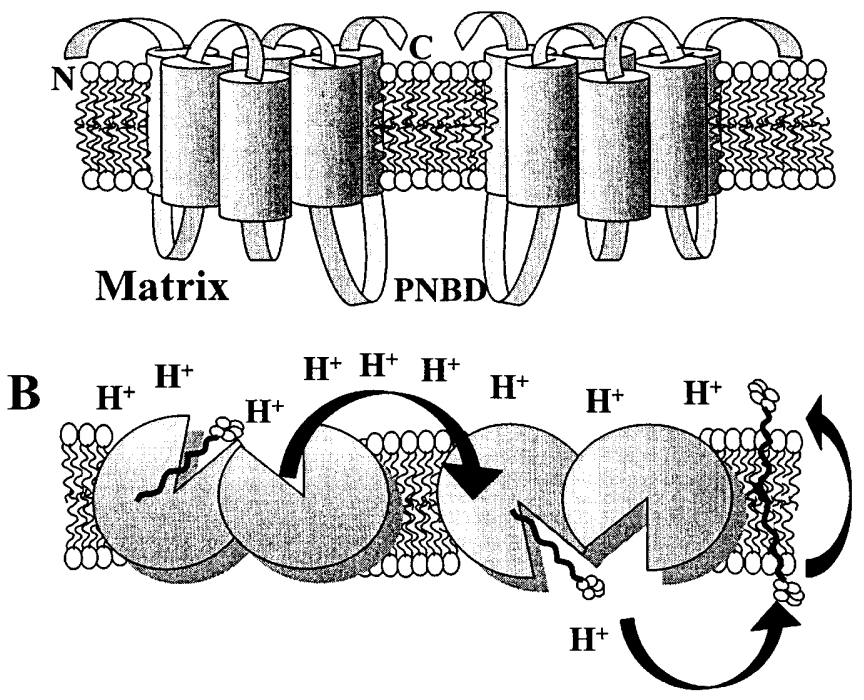

C

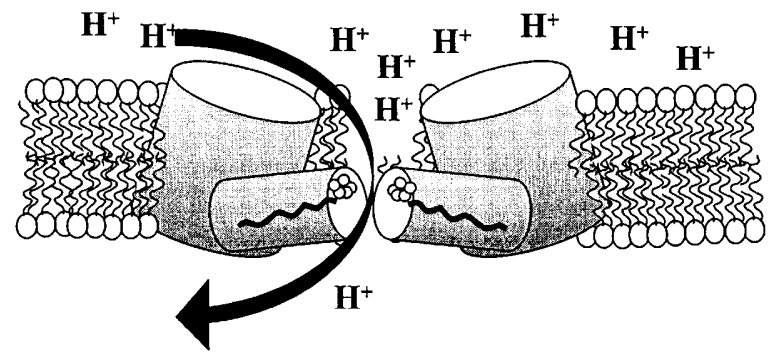

Fig. 2. A The three-dimensional structure of UCP1 is not known. However, UCP1 is a dimeric protein present in the mitochondrial membrane. Both the N- and C-terminal amino acids face the intramembrane space. The protein is believed to consist of $6 \alpha \alpha$-helices connected by loops with the third matrix side loop containing the purine nucleotide-binding domain (PNBD), which is involved in regulation of proton translocating activity. Structures of UCP2 and UCP3 are believed to be similar because of the high sequence similarity (Adapted from reference 30). B In the fatty acid protonophore (or flip-flop) model, UCP1 is a carrier of fatty acid anions, which are transported by UCP1 from the matrix side to the intramembrane space. Here, the anion combines with a proton, becomes electrically neutral and flips back through the membrane and releases the proton in the matrix (31). C The channel model predicts a two-domain structure of UCP1 with a pore domain and a gating domain, which allows protons to pass through. Fatty acid carboxy groups participate in the proton transport by providing $\mathrm{H}^{+}$-buffering capacity (32)

for phosphorylation would be advantageous. The cost of protecting from ROS is energy being wasted by uncoupling proteins as heat $[2,6]$. The generation of ROS seems to be lower in the presence of UCPs. Fat oxidation increases ROS generation, and UCP2 mRNA is induced in fatty liver hepatocytes of $o b / o b$ mice, where the proton permeability of liver mitochondria is increased and the ATP levels decreased $[50,51]$. More direct evidence is obtained from UCP2 and UCP3 knock-out mice, which display in- creased amounts of ROS in macrophages and skeletal muscle, respectively $[52,53]$.

\section{Evidence for uncoupling activity of UCP1, UCP2 and UCP3}

It is generally accepted that UCP1 catalyses proton transport and is responsible for cold-induced thermogenesis in BAT [54,55]. Because of the similarity between UCP1, -2 and -3 , it seemed probable that UCP2 and -3 would have the same function. However, the evidence of a proton leaking function for uncoupling activity of UCP2 and UCP3 is not clear.

UCP2 and UCP3 overexpressed in yeast were less regulated by nucleotides and NEFA than UCP1 [56-60]. This could be due to innate properties of $\mathrm{UCP} 2$ and UCP3 or to a lack of regulators normally present in the mitochondrial membrane. The absence of nucleotide regulated proton leak of BAT in UCP1 knock-out mice argues against the uncoupling activity of UCP2 and UCP3 [61]. Furthermore, the same conditions which up-regulate UCP2 or UCP3 expression do not change mitochondrial membrane potential [62]. However, the growth of UCP2 or UCP3 transformed yeast in aerobic conditions is severely stunted suggesting a reduced efficiency of oxygen dependent respiration and that UCP2 and UCP3 overexpressed in yeast depolarises the mitochondrial membrane $[35,36,39,59,63]$. Recent studies of UCP2 and UCP3 knock-out mice suggest that UCP2 and -3 do have uncoupling activity. The mitochondria were shown to have decreased state 4 respiration and were, therefore, more coupled [52, 53, 64]. Furthermore, in the presence of coenzyme Q, UCP2 and UCP3 were shown to have proton transport activity similar to that of UCP1 [65]. Because retinoids and coenzyme Q have been shown to increase UCP2 activity [66], model systems allowing reliable estimation of proton leak in the uncoupling protein homologues could soon be defined.

The short UCP3 isoform, UCP3S, appears less likely than UCP3L to uncouple in some, but not all, functional assays. There is evidence of similar uncoupling for UCP3S compared with UCP3L in studies on yeast mitochondrial membrane potential $[59,60,67$, 68] but UCP3S does not inhibit yeast growth to the same extent as UCP3L and therefore might have a smaller uncoupling function [60,67]. A lower import rate of UCP3S to the mitochondria has also been reported [68]. 
Genomic organisation of $U C P 1$ :

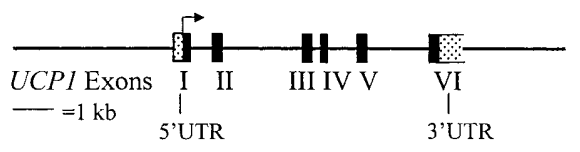

Genomic organisation of $U C P 3$ and $U C P 2$ :

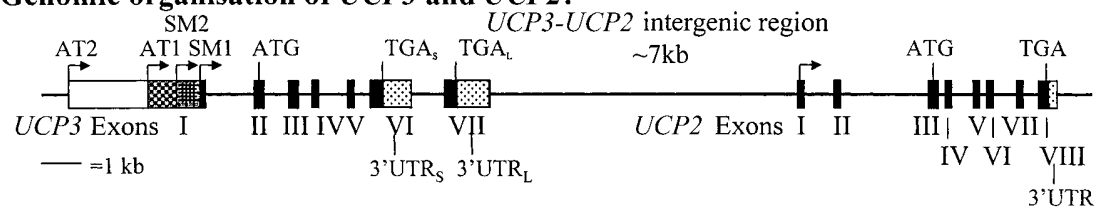

Fig. 3. Organisation of the UCP1 gene and the UCP3-UCP2 genomic region in human beings. The chromosomal localisation of UCP1 in human beings is on chromosome 4 and human UCP 2 and -3 are present on chromosome $11 \mathrm{q} 13$ with the transcription initiation of UCP2 placed only $7-8 \mathrm{~kb}$ downstream of the UCP3 stop codon. All three proteins have relatively few exons ( 6 to 8 ) and the coding sequence is confined to 6 exons in all of these. Exon 1 and 2 of UCP2 are untranslated and in human UCP3 there is at least one untranslated exon and multiple transcription initiation sites. $A T 1$ and $A T 2$, adipose tissue transcription initiation sites 1 and 2,; SM1 and $S M 2$, skeletal muscle transcription initiation site 1 and 2. Arrows indicate the transcription initiation sites; ATG and TGA are the start and stop codons, respectively. TGA ' $S$ ' and ' $L$ ' denotes UCP3S and UCP3L stop codons. Database acc. no. are: UCP1: NT022840, X51952-X51955, UCP2: AF096289, UCP3: AF012196-AF012202

\section{Transgenic approaches to elucidate function and importance of UCPs in body weight homeostasis}

Transgenic and knock-out methods are increasingly common tools for investigating the impact of overexpression or the absence of single genes on the mouse phenotype. These models could be constructed in a site-specific manner to estimate the effect on individual tissues. UCP1 was removed through ablation of the brown fat depot (Table 1) [69], providing evi- dence that UCP1 had an important role in whole body energy homeostasis in mice. The UCP1 knockout mouse, however, was not obese and merely showed sensitivity towards exposure to cold [70] but the respiration of BAT mitochondria of UCP1-/mice was more coupled compared with wild type mice [71].

Another approach was to overexpress UCP1 in WAT mice who were expected to be lean due to constitutive expression of UCP1 [72]. However, the UCP1WAT mice were similar to wild type mice until they were fed a diet high in saturated fat, for which they were obesity resistant. UCP1 is not massively overexpressed in WAT but does reduce the membrane potential of mitochondria [73]. UCP1 has also been ectopically expressed in skeletal muscle (UCP1-skm), which had a severe impact on the phenotype (Table 1) [74]. The UCP1-skm mice had an improved glucose tolerance, which was enhanced compared with wild type mice when on a high-fat diet. The phenotype of the UCP1-skm mouse is similar to the UCP3-skeletal muscle (UCP3-skm) overexpression model [75]. One difference between UCP1-skm and UCP3-skm mice was that the UCP3-skm transgenic strain massively overexpressed the protein, whereas low expression of UCP1 in skeletal muscle could induce the phenotype. These apparent differences in specific activity between UCP1 and UCP3 could be due to the absence

Table 1. Phenotypes of knock-out or transgenic mice models of $U C P 1, U C P 2$ and $U C P 3$

\begin{tabular}{|c|c|c|c|}
\hline Mode & Molecular description & Phenotype & Reference \\
\hline UCP-DTA & Ablation of BAT & Maturity-onset and diet-induced obesity. Hyperphagic & Lowell et al. 1993 [69] \\
\hline UCP1-KO & Disruption of $U C P 1$ gene & Cold-sensitive, normal body weight homeostasis & Enerback et al. 1997 [70] \\
\hline UCP1-WAT & $\begin{array}{l}\text { Transgenic expression of } \\
\text { UCP1 in WAT }\end{array}$ & $\begin{array}{l}\text { Sensitive to diet-induced obesity. Proton leak of WAT- } \\
\text { mitochondria increased }\end{array}$ & Kopecky et al. 1995[72,73] \\
\hline UCP1-skm & $\begin{array}{l}\text { Low transgenic expression } \\
\text { of UCP1 in skeletal muscle }\end{array}$ & $\begin{array}{l}\text { Lean phenotype. Resistant to diet-induced obesity. } \\
\text { Proton leak of skeletal muscle mitochondria increased }\end{array}$ & Li et al. $2000[74]$ \\
\hline UCP3-skm & $\begin{array}{l}\text { High transgenic expression } \\
\text { of UCP3 in skeletal muscle }\end{array}$ & $\begin{array}{l}\text { Lean phenotype. Resistant to diet-induced obesity. } \\
\text { Proton leak of skeletal muscle mitochondria increased }\end{array}$ & Clapham et al. 2000 [75] \\
\hline
\end{tabular}

$D T A$, diphtheria toxin A-chain; BAT, brown adipose tissue; WAT, white adipose tissue; skm, skeletal muscle 
of inhibition of UCP1 or depletion of UCP3 activators in skeletal muscle. However, a probable explanation is that UCP1 is more effective in dissipating the mitochondrial proton gradient.

Although UCP3 null mice could be expected to become obese, two UCP3 knock-out mice, generated on different mouse strain backgrounds, did not become obese when placed on a normal or on a high fat diet $[53,64]$. The UCP3 knock-out mice had increased energy coupling of their mitochondria, which was due to reduced proton leak [53, 64]. Because the formation of reactive oxygen species increased in UCP3 knock-out mice, UCP3 could have a role in apoptosis and ageing, though experiments still need to prove this hypothesis [6]. The UCP2 knock-out mouse is not obese or resistant to diet-induced obesity [52]. Furthermore, these mice have a normal body temperature regulation, indicating that $\mathrm{UCP} 2$ is not essential for maintaining body temperature or preventing obesity. The increase in ROS production by macrophages probably caused the observed resistance to toxoplasmosis. UCP2 knockout mice with hyperinsulinaemia have also been reported [76].

In normal rat islets or insulinoma cells, adenovirus mediated overexpression of UCP2 inhibits glucose stimulated insulin secretion [77, 78] but in Zucker diabetic fatty rats, it had the opposite effect [79]. Because the amount of insulin is normal in islets overexpressing $U C P 2$ mRNA, UCP2 might not decrease biosynthesis of insulin and UCP2 might have a crucial role in the regulation of insulin secretion [77]. This data suggests UCP2 could have a regulatory function in the beta-cell and up regulation or down regulation of UCP2 activity could influence glucose homeostasis.

\section{Regulation of UCP1, UCP2, and UCP3 messenger RNA expression}

Almost all studies describing UCP2 and UCP3 expression have investigated mRNA content rather than protein content and so overlook possible posttranscriptional regulation. They have done this mainly due to difficulties in obtaining specific and sensitive antibodies for UCP2 and UCP3 [80, 81]. The amount of protein antigen seems to mirror the expression levels of mRNA, albeit with fewer fluctuations [80]. However, a recent study suggests that UCP2 mRNA expression does not predict the expression of UCP2 protein in vivo, because $\mathrm{UCP} 2$ is subject to translational regulation in addition to mRNA regulation [81]. Furthermore, mitochondria from tissues expressing increased amounts of UCP2 or UCP3 do not show increased proton leak [62]. Consequently, one must be careful in extrapolating from mRNA regulation to protein content or activity.
UCPs are regulated by a variety of stimuli (Table 2). In general $U C P 1, U C P 2$ and $U C P 3$ mRNA are only weakly regulated by leptin, glucocorticoids and insulin [39, 82-85]. Both TNF- $\alpha$ and LPS strongly activate $U C P 2$ expression providing a link to the immune system [86]. Thyroid hormones consistently up-regulate $U C P$ mRNA levels suggesting a thermogenic function for UCPs [87]. The $\beta 3$-adrenergic regulation of $U C P$ mRNA transcripts, observed in different tissues and in different animal models, could depend on different $\beta 3$-agonists $[39,88]$. PPAR agonists (including TZDs) up-regulate $U C P 2$ mRNA expression in WAT [89-91] (Table 2). However, in human beings $U C P 2$ or $U C P 3$ expression in skeletal muscle and $U C P 2$ expression in WAT is not changed by troglitazone treatment [92].

The original brown fat uncoupling protein (UCP1) is strongly up-regulated by cold (Table 3 ), but the $U C P 2$ and -3 transcripts are up-regulated a modest twofold by cold in a time-dependent fashion [93].

Endurance training could be expected to diminish $U C P 2$ and $U C P 3$ expression, in order to preserve energy for physical activity rather than thermogenesis. The effect of chronic exercise is to reduce $U C P 2$ and UCP3 mRNA expression in skeletal muscle of rats [94]. In humans, humans who have undergone endurance training have similar or lower skeletal muscle content of UCP2 and -3 mRNA compared with subjects who have not [95] (Table 3).

In response to a diet with a high fat content a number of obesity resistant mice strains double their expression of $U C P 2$ mRNA in WAT, whereas obesity prone strains only increase $U C P 2$ mRNA slightly [35]. High fat feeding up-regulates $U C P 3$ in skeletal muscle but not in BAT [96] (Table 3). The increase of $U C P 2$ mRNA expression in WAT and $U C P 3$ in skeletal muscle of animals that are fed with high energy food, suggests that UCP2 and UCP3 could play a part in the mechanisms that counteract obesity. However, fasting or food-restriction consistently up-regulates $U C P 3$ in skeletal muscle of rodents, and down-regulates $U C P 3$ in BAT [97]. In human beings, both $U C P 2$ and $U C P 3$ are up-regulated in WAT in patients undergoing a short-term but not a long-term diet [85]. The plasma non-esterified fatty acid concentrations during fasting correlates with $U C P 2$ and $U C P 3$ expression in skeletal muscle of rodents and humans (Table 3) [84], indicating a role for UCP3 and/or UCP2 in lipid handling or substrate partitioning.

The induction by fasting and peroxisome proliferators indicates lipids are involved as fuel substrates [98]. However, up regulation of mRNA expression in response to thyroid hormone, cold, $\beta 3$-adrenergic agonists and high-fat diets suggests an involvement in the regulation of energy expenditure. The hypothesis that UCP2 and UCP3 reduces the formation of reactive oxygen species fits with the induction of 
Table 2. Regulation of $U C P$ mRNA expression under various hormonal or metabolic influences. Both mRNA and protein levels measured for UCP1

\begin{tabular}{|c|c|c|c|c|c|c|c|c|}
\hline & \multirow{2}{*}{$\begin{array}{l}U C P 1 \\
\text { BAT }\end{array}$} & \multicolumn{4}{|l|}{$U C P 2$} & \multicolumn{3}{|l|}{$U C P 3$} \\
\hline & & $\mathrm{BAT}$ & WAT & $\begin{array}{l}\text { Skeletal } \\
\text { muscle }\end{array}$ & Other & $\mathrm{BAT}$ & WAT & $\begin{array}{l}\text { Skeletal } \\
\text { muscle }\end{array}$ \\
\hline Leptin & $\uparrow$ & $\rightarrow$ & $\uparrow$ & $\rightarrow$ & - & $\uparrow$ & - & $\uparrow \rightarrow$ \\
\hline Insulin & $\uparrow$ & $\rightarrow$ & $\rightarrow$ & $\rightarrow$ & - & $\rightarrow$ & - & $\rightarrow$ \\
\hline Glucocorticoids & $\downarrow$ & $\downarrow$ & - & $\downarrow$ & - & $\downarrow$ & - & $\uparrow / \rightarrow$ \\
\hline $\mathrm{T} 3$ & $\uparrow$ & $\uparrow$ & $\uparrow$ & $\uparrow$ & - & $\uparrow$ & - & $\uparrow$ \\
\hline$\beta \beta 3$-adrenergic drugs & $\uparrow$ & $\rightarrow$ & $\uparrow$ & $\uparrow \rightarrow$ & $\uparrow a$ & $\rightarrow$ & $\uparrow$ & $\uparrow \rightarrow$ \\
\hline
\end{tabular}

${ }^{a}$ Liver

${ }^{\mathrm{b}}$ Pancreatic islets

$B A T$, brown adipose tissue; $W A T$, white adipose tissue

Table 3. Regulation of $U C P$ mRNA expression under different environmental and physiological influences ${ }^{\mathrm{a}}$

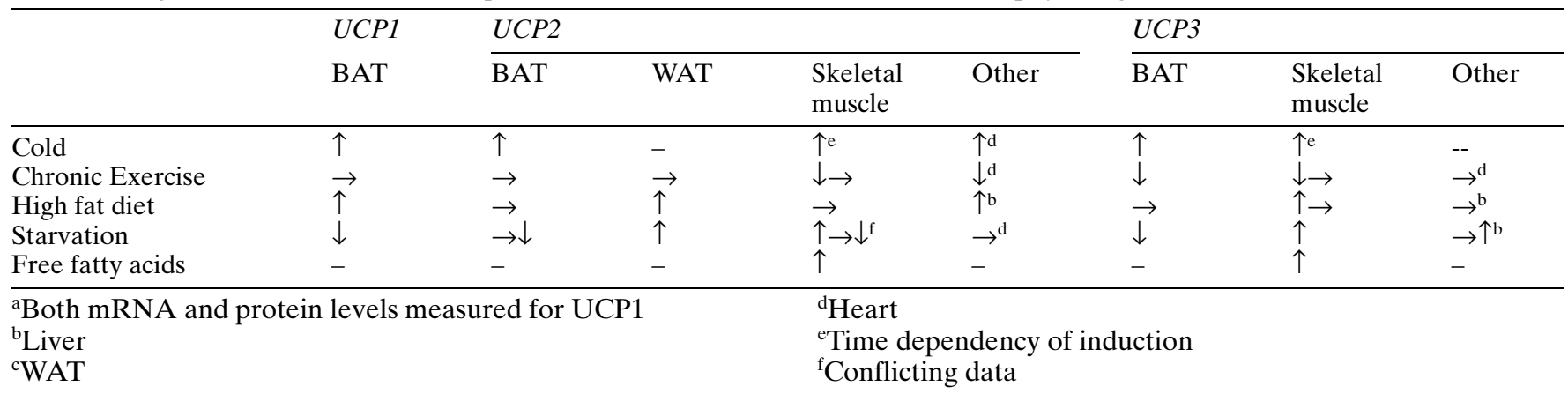

UCP2 and UCP3 during cold, fasting and high fat feeding because these conditions require lipid oxidation and thus high activity of the respiratory chain. Interestingly, reduced ROS due to partial uncoupling by UCP 2 or UCP 3 could represent a link to the "thinness and longevity" phenomenon observed in rodents when diet restrictions increase their life span by up to $50 \%$ [99, 100]. However, it cannot be excluded that essential thermogenesis is required by muscles during fasting, when physical activity is often reduced, and that $\mathrm{UCP} 2$ and $\mathrm{UCP} 3$ are up-regulated to serve that purpose.

\section{Human studies of UCP expression in Type II diabetes and obesity}

The UCP1 mRNA in the intraperitoneal fat of obese subjects is $50 \%$ lower than in normal weight subjects [101], although the amounts of brown adipocytes interspersed in the white fat depots in adult human beings' is low (approximately 1/200 white adipocytes) $[102,103]$.

$U C P 2$ mRNA expression is also decreased in intraperitoneal WAT in obese subjects compared with their lean control subjects [104]. In subcutaneous fat, however, there is no difference between obese and lean subjects regarding $U C P 2$ expression $[85$,
104]. In skeletal muscle, $U C P 2$ mRNA expression is reported to be higher, equal or lower in obese human beings compared with lean subjects [85, $105,106]$. These studies comprised very few subjects and cannot therefore be considered representative.

In weight-reduced formerly obese subjects, $U C P 3$ mRNA expression in skeletal muscle seem to decrease below amounts in lean control subjects [107] perhaps explaining in part the reduced metabolic rate found in previously obese subjects [23]. When comparing obese and lean subjects, $U C P 3$ expression in skeletal muscle is generally not affected by obesity, and the expression of UCP3S and UCP3L are similar (Table 4) [85, 105, 107-109].

Both $U C P 2$ and $U C P 3$ skeletal muscle mRNA increased in a similar way in lean and obese subjects undergoing either fasting or low calorie diet [85-110]. These findings contrast with the regulation found in Type II diabetic subjects undergoing fasting, because fasting does not induce UCP2 or UCP3 mRNA expression in skeletal muscle of Type II diabetic patients [110]. In Type II diabetic subjects, the context of both $U C P 2$ and $U C P 3$ mRNA in skeletal muscle increases compared with weight-matched, glucose-tolerant subjects $[110,111]$. However, a lower expression of $U C P 3$ mRNA in Type II diabetic patients has also been reported [112]. 
Table 4. Regulation of $U C P$ mRNA expression in obesity and Type II diabetes in human patients (WAT white adipose tissue, $B A T$ brown adipose tissue)

\begin{tabular}{|c|c|c|c|c|}
\hline & \multirow{2}{*}{$\begin{array}{l}U C P 1 \\
\text { WAT }\end{array}$} & \multicolumn{2}{|l|}{$U C P 2$} & \multirow{2}{*}{$\begin{array}{l}\text { UCP3 } \\
\text { Skeletal } \\
\text { muscle }\end{array}$} \\
\hline & & WAT & $\begin{array}{l}\text { Skeletal } \\
\text { muscle }\end{array}$ & \\
\hline $\begin{array}{l}\text { Human subjects } \\
\text { Obesity }\end{array}$ & $\downarrow$ & $\rightarrow^{\mathrm{a}} \downarrow^{\mathrm{b}}$ & $\uparrow \downarrow \rightarrow$ & $\rightarrow$ \\
\hline Type II diabetes & - & - & $\rightarrow \uparrow$ & $\downarrow \uparrow$ \\
\hline
\end{tabular}

a Intraperitoneal fat

${ }^{\mathrm{b}}$ Subcutaneous fat

Studies of $U C P 2$ and -3 mRNA expression in obese and Type II diabetic patients or both compared with control subjects have been difficult to reproduce (Table 4). This could be due to the small sample sizes but other factors such as different muscle groups investigated, sampling schemes and diet composition are also probable causes of the low reproducibility. Furthermore, there seems to be a high inter-individual variability in the mRNA expression of $U C P$ homologues. Whether this is due to primary differences in the expression of $U C P 2$ or -3 or to varying concentrations of circulating hormones and nutritional factors is not known.

\section{Correlations between expression levels of UCP2 and UCP3 and sub-phenotypes of human obesity}

Studies suggest that $U C P 2$ mRNA in WAT is positively correlated with BMI and RMR (adjusted for fat free mass) $[85,111,113]$. Changes in UCP2 mRNA expression in WAT in subjects on a low calorie diet have been positively correlated with corresponding changes in 24h-EE [114]. However, other studies suggest no or negative correlations between $U C P 2$ mRNA expression in WAT and BMI, body fat content, concentrations of leptin, free fatty acids or insulin $[114,115]$. In skeletal muscle, $U C P 2$ mRNA is positively correlated with BMI, body fat content and respiratory quotient, but other studies of skeletal muscle identify no such relationships [106, 111, 116, 117].

$U C P 3$ expression in skeletal muscle is positively correlated to concentrations of non-esterified fatty acids [110, 117]. In addition, 24h-EE has been positively correlated with UCP3 expression (adjusted for both fat mass and fat free mass) and negatively correlated with BMI [116].

\section{UCPs: candidate genes for obesity or Type II diabetes}

Because UCP1, UCP2 and UCP3 have been found to decrease membrane potential and increase ther- mogenesis [118], all three genes are regarded as candidate genes for obesity and Type II diabetes. However, based on the expression pattern, UCP2 and $U C P 3$ could be the more obvious candidate genes because of the large contribution of skeletal muscle to the basal metabolic rate, where $U C P 2$ and UCP3 are co-expressed [8]. Mutations reducing the activity or expression of either protein could diminish regulated or basal energy expenditure by increasing the coupling of oxidative phosphorylation.

Nevertheless, certain observations speak against a role for UCP2 and -3 as proton translocators involved in regulation of energy expenditure. The tissue distribution does not quite match the proton leaks measured, because some tissues high in $U C P 2$ have a low proton leak and vice versa [10]. Moreover, the observation that starvation increases $U C P 2$ and $U C P 3$ mRNA and protein in WAT and skeletal muscle without increasing the proton leak argues against an uncoupling function of UCP2 and UCP3 [62]. As long as regulators of UCP2 and UCP3 activity have not been identified, care is needed when extrapolating from mRNA or protein expression to protein activity. There is no reason to think that UCP2 and UCP3 will be constitutively active when UCP1 activity is, in fact, highly regulated.

Data derived from overexpression of UCP1 and UCP3 in WAT and skeletal muscle indicate that a pharmacological increase of UCP activity could prevent or alleviate obesity in human subjects. The overexpression of UCP1 and UCP3 in WAT and skeletal muscle causes leanness. That lack of UCP1 and UCP3 in mice does not cause susceptibility to obesity could therefore be considered illogical. An explanation for this observation could be that redundancy in skeletal muscle where UCP2 and UCP3 are co-expressed. UCP2 is in fact up-regulated in UCP3 knock-out mice [64] and UCP1 is up-regulated in WAT of UCP2 knock-out mice [52] but it is not known if this causes the lack of obesity susceptibility in these mice is not known. Generation of UCP1, UCP2 and UCP3 triple knock-out mice will probably resolve this issue. In addition, the overexpression data in mice might arise from a pathological over loading of mitochondrial membranes. Because even a low UCP1 expression in skeletal muscle caused the lean phenotype, this is, however, not probable [74].

Even though the distantly related proteins, UCP4 and UCP5, are predominantly expressed in the brain, they could have a function or activity that compensates for the absence of UCP2 or UCP3. Both UCP4 and UCP5/BMCP1 have been shown to reduce mitochondrial membrane potential in yeast $[40,41,119]$. Furthermore, the mRNA regulation of UCP5 is consistent with its having a role in energy expenditure 
A) Identified variants in the $U C P 1$ region:

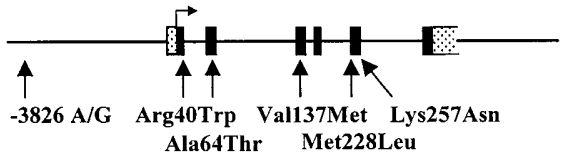

B) Common variants in the $U C P 3-U C P 2$ region:

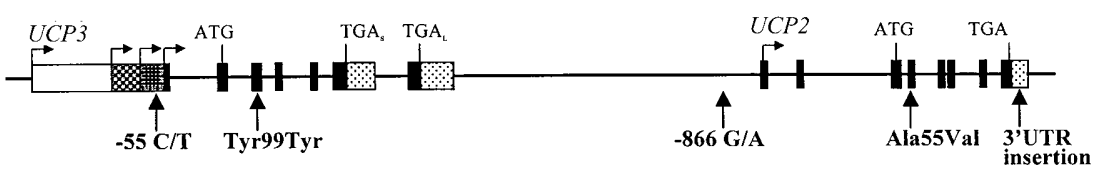

C) Rare or less common variants in the $U C P 3-U C P 2$ region:

$\begin{array}{lll} & \text { Missense: } & \text { Silent or intron: } \\ \text { UCP3: } & \text { Va19Met } & \text { Ala83Ala } \\ & \text { Arg70Trp } & \text { Val102Ile } \\ & \text { Gly84Ser } & \text { Exon 4, 5' of 5' splice site: } 46 \mathrm{~A} / \mathrm{T}, 47 \mathrm{~A} / \mathrm{G}, 96 \mathrm{C} / \mathrm{T}, 143 \mathrm{~A} / \mathrm{G} \\ & \text { R143X } & \text { Exon 5, 5' of 5' splice site: } 36 \mathrm{C} / \mathrm{T} \\ & \text { Arg282Cys } & \text { Ile147Ile } \\ & \text { Arg308Trp } & \text { Tyr210Tyr } \\ & \text { Exon 6 G/A splice } & \text { Arg244Arg } \\ & & -850 \mathrm{G} / \mathrm{A},-337 \mathrm{C} / \mathrm{G},-41 \mathrm{G} / \mathrm{T},-28 \mathrm{insT},-5 \text { insertion of } 13 \mathrm{bp} \\ \boldsymbol{U C P 2 :} & \text { Gly85Ser } & \text { 5'UTR: }+45 \mathrm{C} / \mathrm{T},+53 \mathrm{G} / \mathrm{C},+123 \mathrm{C} / \mathrm{T}\end{array}$

Fig. 4. SNP-map of $\mathbf{A}$ the $U C P 1$ gene and $\mathbf{B}$ common SNPs in the $U C P 3-U C P 2$ genomic region. $\mathbf{C}$ Table of less common variants identified in $U C P 3$ and $U C P 2$. Genetic variants are from references cited in the text

because UCP5 mRNA expression, in contrast to $\mathrm{UCP} 2$ and UCP3, decreases in liver but not in brain during fasting [119]. Thus, the influence of other UCP homologues on whole body energy homeostasis cannot be excluded.

The presence of mutations in the $U C P$ genes or regulatory regions could, hypothetically, cause obesity - if function is decreased - or leanness - if function is increased - or contribute to development of Type II diabetes, either directly through the effect of betacells or as a consequence of obesity.

UCPs therefore probably have a function in regulating ROS, body weight and glucose homeostasis. Identifying mutations or polymorphisms in these genes and determining whether these are associated with obesity, Type II diabetes or a related phenotype will therefore throw light on the role of UCP2 or UCP3 in human obesity or Type II diabetes.

\section{Genetic variation in the coding region of UCP1}

Though there are no discernible brown fat depots in adult human beings, brown adipocytes expressing UCP1 are interspersed among white adipocytes $[102,120]$ and several SNPs are present in the human UCP1 gene [121, 122] (Fig.4). None of these are, however, associated with obesity or Type II diabetes, and none of the identified polymorphisms affect amino acid residues that have been identified as causing functional impairment of UCP1 when mu- tated [32]. It seems that variation in the coding region of $U C P 1$ though frequent, does not lead to obesity.

\section{A possible synergistic effect of a UCP1 promoter variant and a $\beta 3$-Adrenergic receptor variant}

The frequent ag substitution at position -3826 upstream of the $U C P 1$ gene has been related for a long time to obesity and weight gain [123]. The functional areas of the human UCP1 promoter have only recently been investigated [124], and it appears that the -3826 polymorphism is close to, but not directly in, the human enhancer region. Whether the substitution has a functional impact has still to be investigated. The discovery that the $\beta 3$-adrenergic receptor ( $\beta 3$ $A R$ ) polymorphism (Trp64Arg) acted synergistically with the -3826 UCP1 G-allele to increase weight gain [125] sparked a number of studies (Table 5). The general consensus is that in cross-sectional studies there is no difference between the BMI of wild type and double heterozygotic subjects for the UCP1 and $\beta 3-A R$ polymorphisms [125-131]. However, longitudinal studies indicate that there could be an increased risk of weight gain after follow-up or lower weight loss during low calorie dieting in double heterozygotic subjects [130-134]. A reduced BMR in the double heterozygotic subjects might explain this observation [132].

The $U C P 1$ gene is, at least in rodents, directly regulated by adrenergic stimuli acting in part through the $\beta 3$-adrenergic receptor. Hence, a synergistic effect could occur if the function or expression of the $\beta 3-A R$ and $U C P 1$ genes were reduced. This would, in turn, result in an increased risk of weight gain over time or a reduced responsiveness towards weight loss. However, meta-analyses of the Arg64 variant of the $\beta 3-A R$ have found no or very modest 
Table 5. Studies of the synergistic effects of uncoupling protein $1-3826 \mathrm{a} / \mathrm{g}$ and the $\beta \beta 3$ adrenergic receptor codon $64 \mathrm{Trp} / \mathrm{Arg}$ polymorphisms in obese, Type II diabetic or glucose tolerant control subjects ${ }^{\mathrm{a}}$

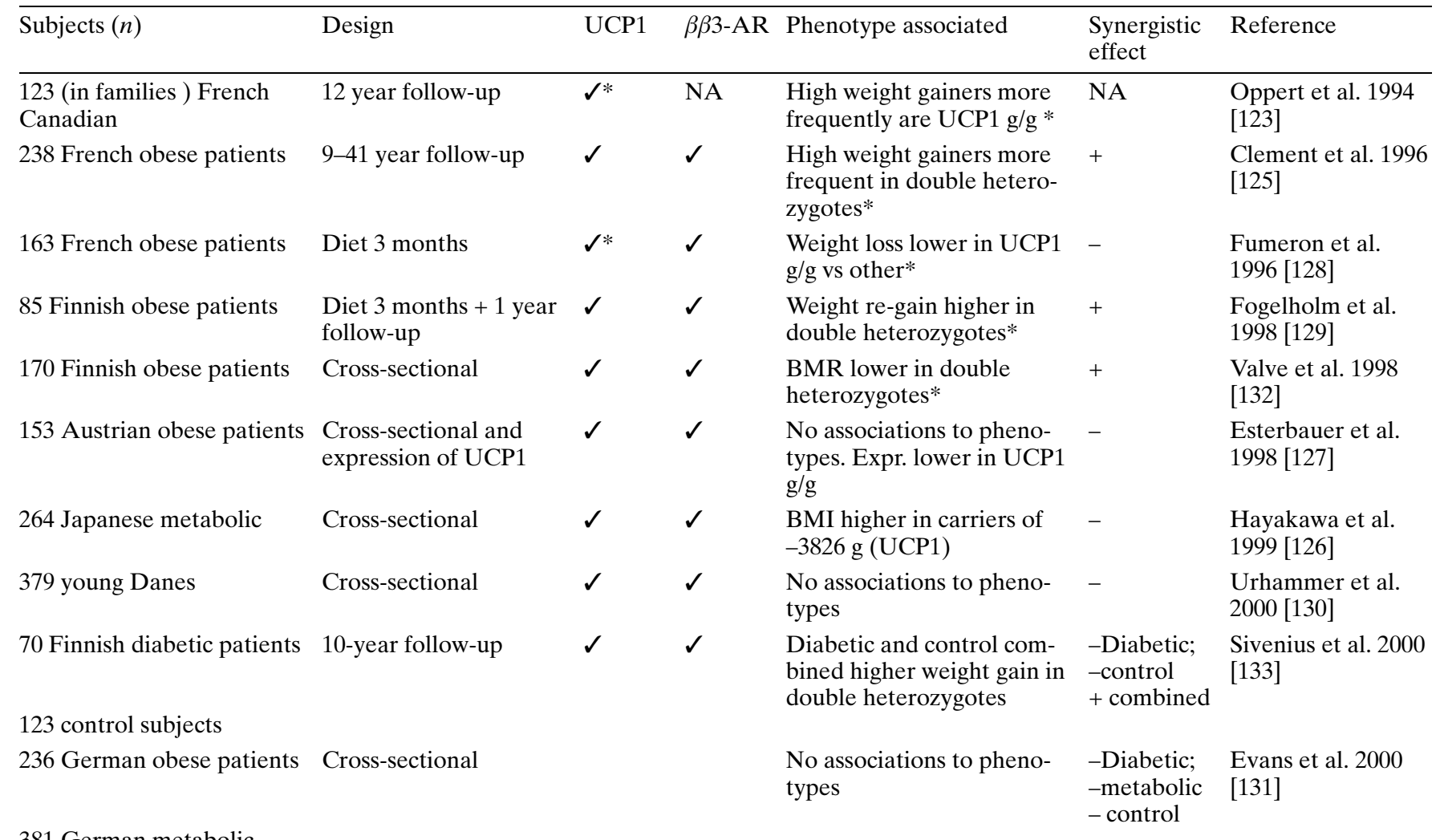

381 German metabolic

198 control subjects

$* p<0.05$ with respect to weight gain, weight loss or other. Is there a synergistic effect of UCP1 and $\beta$ b3-AR polymorphism? $(p<0.05+$ : yes, -:no). Double heterozygotes are Trp64Arg of b3-AR and a/g -3826 of UCP1. Diabetic patients: Type II diabetic subjects. Metabolic: subjects with the metabolic syndrome, Control subjects: glucose tolerant control subjects

direct effects on BMI [134] although the Arg64 variant of the $\beta 3-A R$ has been shown to reduce function [135]. More proof is needed that the $U C P 1$ promoter polymorphism acts synergistically with the $\beta 3-A R$ variant because large studies with the power to detect even minor effects did not detect this $U C P 1 / \beta 3-A R$ synergism $[130,131]$. To determine synergistic effects of the rare polymorphism in the $\beta 3$-AR with the $U C P 1-3826$ a/g variant, meta-analyses or multi-centre efforts are necessary to detect interactions between two or more genetic variants. An adequate study size is an ever-occurring problem in the genetics of polygenic disorders because the costs of recruiting and examining the subjects exceed the capacity of single research centres. a Some studies are longitudinal follow-up studies; others are diet regimens with short-term follow-up. Unless noted, study groups are of normal weight. UCP1 or $\beta$ b3-AR: Is the UCP1 -3826 or $\beta$ b3-AR Trp64Arg polymorphism, respectively, investigated? ( $\checkmark$ : yes, NA: not applicable)

\section{Linkage data from the UCP2-UCP3 chromosomal region}

Evidence from mRNA expression studies in obesityprone and obesity-resistant animals have shown differences in $U C P 2$ and $U C P 3$ regulation depending on nutrients [136]. The observed differences are probably genetically based and could be due to subtle differences in the regulatory regions of either $U C P 2$ or $U C P 3$, although differences in trans-activating factors could also explain these observations.

$U C P 2$ and $U C P 3$ are situated in close proximity to each other on chromosome 11q13, making it difficult for linkage studies to discern between linkages to either gene because the two genes are usually inherited as one block of DNA. In mice, quantitative traits linked to obesity have been mapped to the $U C P 2$ and $U C P 3$ region and in the GK rat, $U C P 2$ and $U C P 3$ map onto a region of glucose intolerance and adiposity [137-142]. However, genomic regions identified by linkage approaches tend to be rather large 
Table 6. Summary of linkage studies containing markers in the UCP3-UCP2 region on chromosome $11 \mathrm{q} 13^{\mathrm{a}}$

\begin{tabular}{|c|c|c|c|c|c|}
\hline Population & Markers & $n$ & Phenotype & $\mathrm{Lod} / p$ value & Reference \\
\hline $\begin{array}{l}\text { French-Canadian } \\
\text { Caucasians }\end{array}$ & 3 in $\mathrm{UCP} 2 / 3$ region & 640 (ext. fam) & $\begin{array}{l}\text { RMR, fat mass, } \\
\text { BMI }\end{array}$ & $\begin{array}{l}p=2 \cdot 10^{-5} \mathrm{RMR} \\
p=0.02 \text { fat mass; } \\
\text { no linkage to BMI }\end{array}$ & $\begin{array}{l}\text { Bouchard et al. } 1997 \\
\text { [148] }\end{array}$ \\
\hline African-Americans & 2 in UCP3 gene & 100-544 (sib-pairs) & $\begin{array}{l}\text { BMI, \% fat, RMR, } \\
\text { leptin }\end{array}$ & No linkage & Chung et al. 1999 [164] \\
\hline Finnish Caucasians & Genome-wide scan & 719 (sib-pairs) & $\begin{array}{l}\text { Type II diabetes, } \\
\text { fasting serum insulin }\end{array}$ & $\begin{array}{l}\text { Linkage, } \text { Lod }=1.75 \\
\text { and Lod }=2.07\end{array}$ & $\begin{array}{l}\text { Ghosh et al. } 2000 \\
\text { [150], Wata-nabe et al. } \\
2000 \text { [149] }\end{array}$ \\
\hline French Caucasians & Genome-wide scan & 514 (nucl. fam) & Obesity, BMI, leptin & No linkage & Hager et al. 1998 [146] \\
\hline Americans & Genome-wide scan & 513 (nucl. fam) & Obesity, BMI, \% fat & No linkage & Lee et al. 1999 [147] \\
\hline
\end{tabular}

and could contain hundreds of genes, many of which have a function which is still not known.

A number of studies investigating linkage of the human $U C P 2$ and $U C P 3$ region to obesity, Type II diabetes and quantitative intermediary phenotypes are listed in Table 6 . The 11q21-23 region is linked to body fat, 24-h energy expenditure and BMI in obese and/or Type II diabetic Pima Indians [143-145]. However, this locus is probably too far from the UCP2/ $U C P 3$ locus to be caused by variation in these genes. Other reports of genome-wide scans for obesity loci in human subjects have not identified the UCP2/ $U C P 3$ region as one of the contributors to obesity or Type II diabetes [146, 147]. However, RMR has been linked to this locus in French Canadians [148]. Of note, the 11q13 region is weakly linked to Type II diabetes and values of fasting serum insulin in Finnish subjects $[149,150]$. Variation in these two genes could alter sub-phenotypes of obesity or Type II diabetes, such as metabolic rate, energy expenditure or insulin secretion. Linkage studies suggest, however, the $U C P 2 / U C P 3$ region is not linked to overt obesity or Type II diabetes in human patients [151, 152]. A disadvantage of linkage studies is their low power to detect genes containing variants with moderate effects, so that linkage studies are most suited to identifying new genes causing major alterations of a given phenotype.

\section{Impact of UCP2 genetic variation on risk of obesity or Type II diabetes mellitus}

The hypothesis that variation in the novel UCP homologues could contribute to obesity and Type II diabetes resulted in early investigations to identify ge- netic variation. In the $U C P 2$ coding region, two frequent polymorphisms exist: an alanine to valine substitution in codon 55, and a 45 bp insertion-polymorphism in the 3'untranslated region (UTR) (Fig.4). No association studies have found differences in allele or genotype frequencies of the Ala55 Val or the 3'UTR insertion polymorphisms between obese and/ or Type II diabetic subjects and control subjects (Table 7).

However, some studies have reported associations to sub-phenotypes related to obesity. The 3'UTR insertion in heterozygous state was associated with higher values of SMR and 24-h EE and lower BMI, agreeing with a role of UCP2 in controlling energy expenditure in Pima Indians [153]. Moreover, the insertion homozygotic genotype was associated with increased BMI in South Indian females and increased values of serum leptin in British women [154] and in American children of different ethnic origin [155]. One study related the Ala55Val polymorphism to measures of energy expenditure [156], finding adjusted 24-h EE was lower in subjects carrying the Val55Val genotype. However, numerous studies do not support a functional impact of the 3'UTR insertion or the Ala55Val polymorphism in causing obesity or Type II diabetes (Table 6) [157-163].

The 3'UTR $45 \mathrm{bp}$ insertion could hypothetically exert an effect by altering mRNA stability. There is no difference, however, in UCP2 mRNA expression between genotypes in skeletal muscle from Pima Indians [153] and in vitro stabilisation assays have not been published. The Ala55Val polymorphism could be evaluated for a functional impact in vitro in yeast heterologous systems.

Preliminary studies of the proximal $U C P 2$ promoter region identify a number of polymorphisms 
Table 7. Summary of $U C P 2$ association and genotype-phenotype interaction studies in obese, Type II diabetic or glucose tolerant control subjects ${ }^{\mathrm{a}}$

\begin{tabular}{|c|c|c|c|c|c|}
\hline Population & Polymorphism & $\begin{array}{l}n_{\text {affected }} \\
\text { (Allele frequency } \\
\text { in \%) }\end{array}$ & $\begin{array}{l}n_{\text {control }} \\
\text { (Allele frequency } \\
\text { in \%) }\end{array}$ & Phenotypes & Reference \\
\hline Danish Caucasians & Ala55Val & $144(48.3)$ & $182(45.6)$ & $\begin{array}{l}\text { Biochemical and } \\
\text { anthropometrical }\end{array}$ & $\begin{array}{l}\text { Urhammer et al. } 1997 \\
\text { [157] }\end{array}$ \\
\hline Japanese & $\begin{array}{l}\text { Ala55Val; } \\
\text { Ala232Thr }\end{array}$ & $\begin{array}{l}210^{\mathrm{b}}(46.0) ; 210^{\mathrm{b}} \\
(0.7)\end{array}$ & $218(48.4) ; 218(-)^{\mathrm{d}}$ & $\begin{array}{l}\text { Biochemical and } \\
\text { anthropometrical }\end{array}$ & $\begin{array}{l}\text { Kubota et al. } 1998 \\
{[159]}\end{array}$ \\
\hline Swedish Caucasians & Ala55Val & $110^{\mathrm{e}}(50)$ & $90(46.7)$ & RMR & $\begin{array}{l}\text { Klannemark et al. } \\
1998 \text { [160] }\end{array}$ \\
\hline Pima Indians & $\begin{array}{l}\text { Ala55Val; 3'UTR } \\
\text { ins-del }\end{array}$ & $\begin{array}{l}82(57.3) ; 790 \\
(50.2)\end{array}$ & $-;-$ & $\begin{array}{l}\text { BMI* (3'ins); } 24 \mathrm{~h} \\
\text { EE* (3'ins); SMR* } \\
\text { (3'ins) }\end{array}$ & $\begin{array}{l}\text { Walder et al. } 1998 \\
{[153]}\end{array}$ \\
\hline French Caucasians & $\begin{array}{l}\text { Ala55Val; 3'UTR } \\
\text { ins-del; Gly85Ser }\end{array}$ & $\begin{array}{l}72(0.28) \\
483(0.25) \\
72(1.4)\end{array}$ & $\begin{array}{l}36(0.38) \\
113(0.23) \\
120(-)^{\mathrm{d}}\end{array}$ & - & Otabe et al. 1998 [162] \\
\hline German Caucasians & $\begin{array}{l}\text { Ala55Val; 3'UTR } \\
\text { ins }\end{array}$ & $68 ; 68$ & $104\left(37.0^{\mathrm{c}}\right) ; 104\left(29.0^{\mathrm{c}}\right)$ & RMR & Tu et al. 1999 [161] \\
\hline Danish Caucasians & 3'UTR ins-del & $744(30.4)$ & $791(29.6)$ & BMI, weight gain & $\begin{array}{l}\text { Dalgaard et al. } 1999 \\
\text { [158] }\end{array}$ \\
\hline $\begin{array}{l}\text { British and South } \\
\text { Indians }\end{array}$ & 3'UTR ins-del & $91(25.9)$ & $220(18.2)$ & BMI*, Leptin* & $\begin{array}{l}\text { Cassell et al. } 1999 \\
{[154]}\end{array}$ \\
\hline Japanese & $\begin{array}{l}\text { Ala55Val; 3'UTR } \\
\text { ins-del }\end{array}$ & $\begin{array}{l}100^{\mathrm{b}}(43.5) 99^{\mathrm{b}} \\
(18.2)\end{array}$ & $120(47.1) ; 120(20.8)$ & $\begin{array}{l}\text { Biochemical and } \\
\text { anthropometrical }\end{array}$ & $\begin{array}{l}\text { Shiinoki et al. } 1999 \\
\text { [163] }\end{array}$ \\
\hline Danish Caucasians & Ala55Val & - & $60(40.8)$ & $\begin{array}{l}\text { BMI, 24h EE*, } \\
\text { SMR, fat oxidation* }\end{array}$ & $\begin{array}{l}\text { Astrup et al. } 1999 \\
\text { [156] }\end{array}$ \\
\hline $\begin{array}{l}\text { Americans (various } \\
\text { ethnic origin) }\end{array}$ & $\begin{array}{l}\text { Ala55Val; 3'UTR } \\
\text { ins-del }\end{array}$ & 68 (39.2); 68 (25.6) & $-;-$ & $\begin{array}{l}\text { BMI** (3'ins), } \\
\text { body composition* } \\
\text { (3'ins) }\end{array}$ & $\begin{array}{l}\text { Yanovski et al. } 2000 \\
{[155]}\end{array}$ \\
\hline
\end{tabular}

$* p<0.05$ and $* * p<0.001$ between genotype groups for the particular phenotype

aThe frequency of the valine 55 and 3' UTR (untranslated region) insertion is noted in parenthesis after the number of subjects. Unless noted, the affected subjects are obese. $E E$, energy expenditure; $S M R$, sleeping metabolic rate; $R M R$, resting metabolic rate

(Fig.4), but these do not seem to be associated with obesity or sub-phenotypes thereof in Danish Caucasian subjects (LT Dalgaard, O Pedersen, unpublished observations).

\section{The functional impact of UCP3 coding region polymorphisms and mutations}

Although a number of different amino acid substitutions have been reported in the UCP3 gene, most are rare [164-166] (Fig.4). Amino acid polymorphisms in UCP3 do therefore not make a large contribution to susceptibility to common obesity or Type II diabetes [43, 164]. However, the presence of rare but penetrating, variants could cause monogenic obesity. Rare mutations in $U C P 3$ have been identified: Val9Met, Arg70Trp, Val102Ile, Arg143X, Arg282Cys, Arg308Trp [164-166]. In addition, a mutation at the junction of exon 6 and intron 6 , allowing only UCP3 short form to be translated from the

\author{
${ }^{\mathrm{b}}$ Type II diabetic patients \\ 'Data given only on combined allele frequency in both obese \\ and control subjects (no association with obesity) \\ ${ }^{\mathrm{d}} \mathrm{A} / \mathrm{T} 232$ and $\mathrm{G} / \mathrm{S} 85$ not detected in control subjects \\ ${ }^{\mathrm{e}}$ Metabolic syndrome
}

allele (exon 6 ivs $+1 G>A$ ) was detected exclusively in subjects of African origin, with a prevalence of 0.1 of the minor allele (A). The exon 6 ivs $+1 G>A$ polymorphism was associated with reduced fat oxidation and respiratory quotient in carriers and it has been suggested that UCP3 could participate in fuel partitioning [165]. However, other studies have found no evidence that this polymorphism causes obesity, altered fat oxidation or respiratory quotient [164].

In vitro studies of the $U C P 3$ variants show that the codon 9 methionine, isoleucine 102 and codon 143 stop versions of $U C P 3$ are not different from the wild type protein with regard to yeast growth properties or $\mathrm{O}_{2}$-consumption $[67,168]$. However, the mitochondrial membrane potential did not decrease to the membrane potential of UCP3L sample in the codon 143 stop codon construct, implying that this mutation does have a reduced function with regard to uncoupling of the membrane potential [168]. Neither the tryptophan 70 nor cysteine 282 variants uncouple 
the mitochondria of yeast to nearly the same extent as UCP3L wild type does and these mutations therefore severely impair protein function. The Arg308Trp was not investigated in vitro [166]. The predicted functional effect of the exon $6 i v s+1 G>A$ polymorphism is an increased amount of UCP3S protein compared with UCP3L protein and presumably, slightly smaller proton leaks. The increased expression of $\mathrm{UCP} 3 \mathrm{~S}$ is confirmed by RNase protection analysis of skeletal muscle RNA from exon 6 ivs $+1 G>A$-carriers [164].

Functional impairment of UCP3 function by mutations is not well correlated to the clinical findings of massive obesity in the compound heterozygous subject carrying the codon 143 stop mutation and exon 6 ivs $+1 \mathrm{G}>$ A mutation or the co-segregation of obesity and the Ile102 Val variant [165], none of which cause serious derangement of UCP3 protein function compared with the wild type [168]. These observations have been made in a sample of low-income, African-American patients among whom obesity is very prevalent, making it probable that the phenotype segregated with the polymorphic alleles by chance. Furthermore, the Arg282Cys variant was not associated with obesity despite serious functional derangement of the protein [164].

The paucity of common missense polymorphisms in the UCP3 gene excludes the possibility that amino acid changes in UCP 3 cause susceptibility to common obesity or Type II diabetes. In addition, there is no obvious correlation between the functional impairment of UCP3 and severity of obesity in subjects that mutations in UCP3 cannot be concluded to cause severe or monogenic obesity.

\section{Investigations of the promoter region of UCP3 in obese, Type II diabetic and normal glucose-tolerant patients}

The UCP3 $-55 c \rightarrow t$ transition is placed 55 bp upstream of the most commonly used transcription initiation site of skeletal muscle (SM1) [47] (Fig. 4). This polymorphism is potentially interesting because it is placed only $6 \mathrm{bp}$ from the TATA box and $4 \mathrm{bp}$ from a DR1 site. Mobility shift and reporter gene assays show that this DR1 site is part of a retinoic acid response element and that the sequence up to $-61 \mathrm{bp}$ is responsible for the MyoD dependent activity of the $U C P 3$ promoter [169].

The $c / c$ genotype was found to be associated with lower expression of $U C P 3$ mRNA in skeletal muscle biopsies from Pima Indians [170], suggesting that the $-55 t$ allele increases $U C P 3$ mRNA expression compared with the $c$ allele. In Pima Indians, UCP3 skeletal muscle mRNA is closely correlated with a sleeping metabolic rate. However, there was no association between UCP3 mRNA expression and body fat content or BMI [116].
In a French cohort of morbidly obese subjects (predominantly females) the $-55 t / t$ genotype was associated with increased BMI, although the allele and genotype frequencies were equal between the obese subjects and normal weight control subjects [171]. Control subjects carrying the $t / t$ genotype were also slightly heavier than control subjects with other genotypes $(p=0.09)$. In another French population-based study the $-55 \mathrm{t} / \mathrm{t}$ genotype was associated with dyslipidaemia (increased fasting total serum cholesterol, increased fasting serum LDL-cholesterol and fasting serum apolipoprotein B). It has been proposed that the $\mathrm{t}$-allele protects against Type II diabetes, because its frequency was lower among French Type II diabetic patients compared with glucose-tolerant control subjects $(p=0.03)$ [172]. Among South Indian as well as British glucose-tolerant females and Type II diabetic females the $c / t$ and $t / t$ genotypes combined were associated with increased waist-to-hip ratio [173]. However, the -55 $c / t$ UCP3 polymorphism was not associated with obesity or alterations of BMI, waist-to-hip-ratio or fasting serum lipids between genotypes in Danish Caucasian subjects [174]. Thus, at least in some populations this UCP3 promoter polymorphism might be implicated in several phenotypes associated with Type II diabetes and the metabolic syndrome. The mechanisms of this genetic variant are still not known. To determine the possible physiological importance of this polymorphism, more studies, including functional studies and statistical meta-analyses are needed.

\section{Conclusions and perspectives}

The hypothesis that UCPs are candidate genes for human obesity is primarily based on the findings that the proteins act as uncouplers of the yeast mitochondrial membrane. As it is known that chemical uncoupling of the mitochondrial membrane reduces body adiposity, and because lower metabolic rates predicts of weight gain, the hypothesis that common polymorphisms of the $U C P$ genes (coding or regulatory regions) cause lower metabolic rates due to more efficient energy coupling in the mitochondria seems reasonable. Furthermore, genetically engineered mice overexpressing UCP1 and UCP3 are lean and resistant to diet-induced obesity.

Using this hypothesis, investigators including ourselves, studied the coding regions of $U C P 1, U C P 2$ and $U C P 3$ as well as the known regulatory regions for these genes. Prevalent polymorphisms were investigated in the coding, untranslated region and promoters and their impact on obesity, body weight gain, and BMI or Type II diabetes were estimated. Variation in the uncoupling protein genes has been found not to be associated with major alterations of 
body weight, but it is more difficult to estimate the contribution of $U C P$ genes towards polygenic obesity and Type II diabetes.

Studies of yeast and knock-out animals have established that the UCP2 and UCP3 have uncoupling activity. Their proton-leak properties, verified by in vitro studies, are not supported, however, by a direct relation between mRNA expression of UCP2 or UCP3 in various tissues and an increase in proton leak. This throws into doubt the hypothesis that lower proton leak and higher energy coupling leads to susceptibility towards obesity because UCP 2 or UCP3 knockout mice do not become obese.

A key finding on UCP3 from knock-out mice is that the mice show lower proton leak in their mitochondria. An increase in proton leak accompanied by the uncoupling of the mitochondrial membrane might, therefore, not result in reduced energy expenditure or reduced energy expenditure might not be a predictor of future weight gain. Reversing the chain of causality, the proton leak responsible for a portion of the basal metabolic rate probably does not occur through either UCP2 or UCP3, because a lack of either of these does not lead to a reduced metabolic rate. However, the UCP2 and UCP3 genes should not be dismissed until a double knock-out model is available or, even better, a triple knock-out mouse lacking UCP1, 2, and 3. It is clear, though, that studies investigating the nature of proton leaks across the inner mitochondrial membrane are needed to clarify the physiological consequences of increases or decreases in proton leaks. Furthermore, it is evident from transgenic overexpression in mice that UCPs have the ability to cause weight loss when activated making UCPs promising antiobesity drug targets. Given the effect of overexpression of UCP3 and UCP1 in skeletal muscle and WAT, it is clear that these proteins influence metabolic rate.

Even though polymorphisms in the $U C P$ genes have been shown to be associated with obesity, Type II diabetes or sub-phenotypes thereof, their impact on these phenotypes seems to be modest. This is characteristic of polygenetics, where many genes control the phenotype and the same phenotype could be caused by variants in different sets of genes. A major concern with genetic variants with a modest effect is that the population variance of the phenotype could obscure the observable effect of the variant. Therefore, large numbers of well-characterised patients have to be studied to detect the precise effect of a given variant. In addition, more stringent statistical significance criteria are needed for large-scale genome association studies to avoid false positive findings due to the huge number of polymorphisms in the human genome. However, more powerful computational tools will certainly permit the screening of the entire $U C P 1$ or $U C P 2$ -
UCP3 genomic region for polymorphisms in a large number of subjects and thus identify patterns of polymorphisms which could be associated with obesity or Type II diabetes. The next and indispensable step is to verify the functionality of associated variants in cell-based assays or other biochemical studies.

Sources. Current Contents, Medline and PubMed were searched for publications in English containing the words "uncoupling protein", "UCP", "UCP2", "UCP3", "thermogenesis", "proton leak", "brown adipose tissue", "metabolic rate" alone or in conjunction with "obesity" and "diabetes". A $p$ value of less than 0.05 was considered to be statistically significant.

Note added in proof: UCP2 deficient mice secrete more insulin in response to glucose stimulus due to increased ATP levels in pancreatic islets [175]. Furthermore, the $866 \mathrm{~g} /$ a polymorphism of the UCP2 promoter was associated both increased transcriptional activity decreased BMI in middle-aged subjects [176].

Acknowledgements. Cited work from the authors' laboratory has been supported by the University of Copenhagen, the Velux Foundation, the Danish Medical Research Council, the Danish Heart Foundation, the Foundation of Director Jacob Madsen and his wife, Olga Madsen, and the Foundation of King Christian the Xth and EEC grants (BMH4-CT95-0662, BMH4-CT98-3084 and QLRT-199-00546). Furthermore, the authors are grateful to Dr S. Urhammer and Dr N. Din for helpful comments and criticism during the preparation of the manuscript and to Dr F. Geneser for providing material for the figures.

\section{References}

1. Kozak LP, Harper ME (2000) Mitochondrial uncoupling proteins in energy expenditure. Annu Rev Nutr 20: 339-363

2. Boss O, Hagen T, Lowell BB (2000) Uncoupling proteins 2 and 3: potential regulators of mitochondrial energy metabolism. Diabetes 49: 143-156

3. Ricquier D, Bouillaud F (2000) The uncoupling protein homologues: UCP1, UCP2, UCP3, StUCP and AtUCP. Biochem J 345: 161-179

4. Fleury C, Sanchis D (1999) The mitochondrial uncoupling protein-2: current status. Int J Biochem Cell Biol 31: 1261-1278

5. Muzzin P, Boss O, Giacobino JP (1999) Uncoupling protein 3: Its possible biological role and mode of regulation in rodents and humans. J Bioenerg Biomembr 31: 467-473

6. Diehl AM, Hoek JB (1999) Mitochondrial uncoupling: role of uncoupling protein anion carriers and relationship to thermogenesis and weight control "the benefits of losing control". J Bioenerg Biomembr 31: 493-506

7. Mitchell P (1979) Keilin's respiratory chain concept and its chemiosmotic consequences. Science 206: 1148-1159 
8. Rolfe DFS, Brown GC (1997) Cellular-energy utilization and molecular-origin of standard metabolic-rate in mammals. Physiol Rev 77: 731-758

9. Rolfe DF, Newman JM, Buckingham JA, Clark MG, Brand MD (1999) Contribution of mitochondrial proton leak to respiration rate in working skeletal muscle and liver and to SMR. Am J Physiol 276: C692-C699

10. Brand MD, Brindle KM, Buckingham JA, Harper JA, Rolfe DF, Stuart JA (1999) The significance and mechanism of mitochondrial proton conductance. Int J Obes Relat Metab Disord 23: S4-s11

11. Toubro S, Sorensen TI, Ronn B, Christensen NJ, Astrup A (1996) Twenty-four-hour energy expenditure: the role of body composition, thyroid status, sympathetic activity, and family membership. J Clin Endocrinol Metab 81: 2670-2674

12. Saltzman E, Roberts SB (1995) The role of energy expenditure in energy regulation: findings from a decade of research. Nutr Rev 53: 209-220

13. Bogardus C, Lillioja S, Ravussin E et al. (1986) Familial dependence of the resting metabolic rate. $\mathrm{N}$ Engl $\mathrm{J}$ Med 315: 96-100

14. Ravussin E, Bogardus C (1989) Relationship of genetics, age, and physical fitness to daily energy expenditure and fuel utilization. Am J Clin Nutr 49: 968-975

15. Bouchard C, Tremblay A, Nadeau A et al. (1989) Genetic effect in resting and exercise metabolic rates. Metabolism 38: $364-370$

16. Fontaine E, Savard R, Tremblay A, Despres JP, Poehlman E, Bouchard C (1985) Resting metabolic rate in monozygotic and dizygotic twins. Acta Genet Med Gemellol (Roma) 34: 41-47

17. Roberts SB, Savage J, Coward WA, Chew B, Lucas A (1988) Energy expenditure and intake in infants born to lean and overweight mothers. $\mathrm{N}$ Engl J Med 318: 461-466

18. Griffiths M, Payne PR, Stunkard AJ, Rivers JP, Cox M (1990) Metabolic rate and physical development in children at risk of obesity. Lancet 336: 76-78

19. Weigle DS, Levin BE (2000) Defective dietary induction of uncoupling protein 3 in skeletal muscle of obesityprone rats. Obes Res 8: 385-391

20. Seidell JC, Muller DC, Sorkin JD, Andres R (1992) Fasting respiratory exchange ratio and resting metabolic rate as predictors of weight gain: the Baltimore Longitudinal Study on Aging. Int J Obes Relat Metab Disord 16: 667-674

21. Davies PS, Wells JC, Fieldhouse CA, Day JM, Lucas A (1995) Parental body composition and infant energy expenditure. Am J Clin Nutr 61: 1026-1029

22. Goran MI, Carpenter WH, McGloin A, Johnson R, Hardin JM, Weinsier RL (1995) Energy expenditure in children of lean and obese parents. Am J Physiol 268: E917-E924

23. Rosenbaum M, Leibel RL, Hirsch J (1997) Obesity. N Engl J Med 337: 396-407

24. Parascandola J (1974) Dinitrophenol and bioenergetics: an historical perspective. Mol Cell Biochem 5: 69-77

25. Rothwell NJ, Stock MJ, Stribling D (1990) Diet-Induced Thermogenesis. In: Schonbaum E, P Lomax (ed) International Encyclopoedia of Pharmacology and Therapeutics, Pergamon Press, Oxford, pp 309-326

26. Heaton GM, Wagenvoord RJ, Kemp A, Nicholls DG (1978) Brown-adipose-tissue mitochondria: photoaffinity labelling of the regulatory site of energy dissipation. Eur J Biochem 82: 515-521
27. Aquila H, Link TA, Klingenberg M (1985) The uncoupling protein from brown fat mitochondria is related to the mitochondrial ADP/ATP carrier. Analysis of sequence homologies and of folding of the protein in the membrane. EMBO J 4: 2369-2376

28. Silva JE, Rabelo R (1997) Regulation of the uncoupling protein gene expression. Eur J Endocrinol 136: 251-264

29. Echtay KS, Winkler E, Klingenberg M (2000) Coenzyme $\mathrm{Q}$ is an obligatory cofactor for uncoupling protein function. Nature 408: 609-613

30. Gonzalez-Barroso MM, Fleury C, Jimenez MA et al. (1999) Structural and functional study of a conserved region in the uncoupling protein UCP1: the three matrix loops are involved in the control of transport. J Mol Biol 292: $137-149$

31. Garlid KD, Jabaurek M, Jezek P (1998) The mechanism of proton transport mediated by mitochondrial uncoupling proteins. FEBS Lett 438: 10-14

32. Klingenberg M, Huang SG (1999) Structure and function of the uncoupling protein from brown adipose tissue. Biochim Biophys Acta 1415: 271-296

33. Cortez-Pinto H, Zhi-Lin H, Qi-Yang S, Odwin-Da C, Diehl AM (1999) Lipids up-regulate uncoupling protein 2 expression in rat hepatocytes. Gastroenterology 116: 1184-1193

34. Lee FY, Li Y, Zhu H et al. (1999) Tumor necrosis factor increases mitochondrial oxidant production and induces expression of uncoupling protein-2 in the regenerating mice correction of rat liver. Hepatology 29: 677-687

35. Fleury C, Neverova M, Collins S et al. (1997) Uncoupling protein-2: A novel gene linked to obesity and hyperinsulinemia. Nat Genet 15: 269-272

36. Gimeno RE, Dembski M, Weng X et al. (1997) Cloning and characterization of an uncoupling protein homolog: a potential molecular mediator of human thermogenesis. Diabetes 46: 900-906

37. Boss O, Samec S, Paoloni-Giacobino A et al. (1997) Uncoupling protein-3: a new member of the mitochondrial carrier family with tissue-specific expression. FEBS Lett 408: $39-42$

38. Vidal-Puig A, Solanes G, Grujic D, Flier JS, Lowell BB (1997) UCP3: an uncoupling protein homologue expressed preferentially and abundantly in skeletal muscle and brown adipose tissue. Biochem Biophys Res Commun 235: 79-82

39. Gong DW, He Y, Karas M, Reitman M (1997) Uncoupling protein-3 is a mediator of thermogenesis regulated by thyroid hormone, beta3-adrenergic agonists, and leptin. J Biol Chem 272: 24129-24132

40. Sanchis D, Fleury C, Chomiki N et al. (1998) BMCP1, a novel mitochondrial carrier with high expression in the central nervous system of humans and rodents, and respiration uncoupling activity in recombinant yeast. J Biol Chem 273: 34611-34615

41. Mao W, Yu XX, Zhong A et al. (1999) UCP4, a novel brain-specific mitochondrial protein that reduces membrane potential in mammalian cells FEBS Lett 443: 326-330

42. Pecqueur C, Cassard-Doulcier A, Raimbault S et al. (1999) Functional organization of the human uncoupling protein-2 gene, and juxtaposition to the uncoupling protein-3 gene. Biochem Biophys Res Commun 255: $40-46$

43. Urhammer SA, Dalgaard LT, Sorensen TI et al. (1998) Organisation of the coding exons and mutational screen- 
ing of the uncoupling protein 3 gene in subjects with juvenile-onset obesity. Diabetologia 41: 241-244

44. Solanes G, Vidal-Puig A, Grujic D, Flier JS, Lowell BB (1997) The human uncoupling protein-3 gene. Genomic structure, chromosomal localization, and genetic basis for short and long form transcripts. J Biol Chem 272: 25433-25436

45. Cassard AM, Bouillaud F, Mattei MG et al. (1990) Human uncoupling protein gene: structure, comparison with rat gene, and assignment to the long arm of chromosome 4. J Cell Biochem 43: 255-264

46. Negre SA, Hirtz C, Carrera G et al. (1997) A role for uncoupling protein-2 as a regulator of mitochondrial hydrogen peroxide generation. FASEB J 11: 809-815

47. Esterbauer H, Oberkofler H, Krempler F, Strosberg AD, Patsch W (2000) The uncoupling protein-3 gene is transcribed from tissue- specific promoters in humans but not in rodents. J Biol Chem 275: 36394-36399

48. Faggioni R, Shigenaga J, Moser A, Feingold KR, Grunfeld C (1998) Induction of UCP2 gene expression by LPS: a potential mechanism for increased thermogenesis during infection. Biochem Biophys Res Commun 244: $75-78$

49. Busquets S, Sanchis D, Alvarez B, Ricquier D, Lopez-Soriano FJ, Argiles JM (1998) In the rat, tumor necrosis factor alpha administration results in an increase in both UCP2 and UCP3 mRNAs in skeletal muscle: a possible mechanism for cytokine-induced thermogenesis? FEBS Lett 440: 348-350

50. Chavin KD, Yang S, Lin HZ et al. (1999) Obesity induces expression of uncoupling protein-2 in hepatocytes and promotes liver ATP depletion. J Biol Chem 274: 5692-5700

51. Rashid A, Wu TC, Huang CC et al. (1999) Mitochondrial proteins that regulate apoptosis and necrosis are induced in mouse fatty liver. Hepatology 29: 1131-1138

52. Arsenijevic D, Onuma H, Pecqueur C et al. (2000) Disruption of the uncoupling protein-2 gene in mice reveals a role in immunity and reactive oxygen species production. Nat Genet 26: 435-439

53. Vidal-Puig AJ, Grujic D, Zhang CY et al. (2000) Energy metabolism in uncoupling protein 3 gene knock-out mice. J Biol Chem 275: 16258-16266

54. Klingenberg M, Winkler E (1985) The reconstituted isolated uncoupling protein is a membrane potential driven $\mathrm{H}+$ translocator. EMBO J 4: 3087-3092

55. Bouillaud F, Ricquier D, Gulik-Krzywicki T, Gary-Bobo CM (1983) The possible proton translocating activity of the mitochondrial uncoupling protein of brown adipose tissue. Reconstitution studies in liposomes. FEBS Lett 164: 272-276

56. Echtay KS, Liu Q, Caskey T et al. (1999) Regulation of $\mathrm{UCP} 3$ by nucleotides is different from regulation of UCP1. FEBS Lett 450: 8-12

57. Hagen T, Zhang CY, Vianna CR, Lowell BB (2000) Uncoupling proteins 1 and 3 are regulated differently. Biochemistry 39: 5845-5851

58. Jabaurek M, Varecha M, Gimeno RE et al. (1999) Transport function and regulation of mitochondrial uncoupling proteins 2 and 3. J Biol Chem 274: 26003-26007

59. Hinz W, Gruninger S, De Pover A, Chiesi M (1999) Properties of the human long and short isoforms of the uncoupling protein-3 expressed in yeast cells. FEBS Lett 462: 411-415

60. Heidkaemper D, Winkler E, Muller V et al. (2000) The bulk of UCP3 expressed in yeast cells is incompetent for a nucleotide regulated $\mathrm{H}+$ transport. FEBS Lett 480: 265-270

61. Nedergaard J, Matthias A, Golozoubova V, Jacobsson A, Cannon B (1999) UCP1: the original uncoupling protein-and perhaps the only one? New perspectives on $\mathrm{UCP} 1, \mathrm{UCP} 2$, and UCP3 in the light of the bioenergetics of the UCP1-ablated mice. J Bioenerg Biomembr 31: 475-491

62. Cadenas S, Buckingham JA, Samec S et al. (1999) UCP2 and UCP3 rise in starved rat skeletal muscle but mitochondrial proton conductance is unchanged. FEBS Lett 462: $257-260$

63. Zhang CY, Hagen T, Mootha VK, Slieker LJ, Lowell BB (1999) Assessment of uncoupling activity of uncoupling protein 3 using a yeast heterologous expression system. FEBS Lett 449: 129-134

64. Gong DW, Monemdjou S, Gavrilova O et al. (2000) Lack of obesity and normal response to fasting and thyroid hormone in mice lacking uncoupling protein-3. J Biol Chem 275: 16251-16257

65. Echtay KS, Winkler E, Frischmuth K, Klingenberg M (2001) Uncoupling proteins 2 and 3 are highly active $\mathrm{H}+$ transporters and highly nucleotide sensitive when activated by coenzyme Q (ubiquinone). Proc Natl Acad Sci U S A 98: 1416-1421

66. Rial E, Gonzalez-Barroso M, Fleury C et al. (1999) Retinoids activate proton transport by the uncoupling proteins UCP1 and UCP2. Biochem Biophys Res Commun 18: 5827-5833

67. Hagen T, Zhang CY, Slieker LJ, Chung WK, Leibel RL, Lowell BB (1999) Assessment of uncoupling activity of the human uncoupling protein 3 short form and three mutants of the uncoupling protein gene using a yeast heterologous expression system. FEBS Lett 454: 201-206

68. Renold A, Koehler CM, Murphy MP (2000) Mitochondrial import of the long and short isoforms of human uncoupling protein 3. FEBS Lett 465: 135-140

69. Lowell BB, Susulic V, Hamann A et al. (1993) Development of obesity in transgenic mice after genetic ablation of brown adipose tissue Nature 366: 740-742

70. Enerback S, Jacobsson A, Simpson EM et al. (1997) Mice lacking mitochondrial uncoupling protein are cold-sensitive but not obese. Nature 1997 May 1;387(6628):27-8. Nature 387: 90-94

71. Matthias A, Ohlson KB, Fredriksson JM, Jacobsson A, Nedergaard J, Cannon B (2000) Thermogenic responses in brown fat cells are fully UCP1-dependent. UCP2 or UCP3 do not substitute for UCP1 in adrenergically or fatty scid-induced thermogenesis. J Biol Chem 275: 25073-25081

72. Kopecky J, Clarke G, Enerback S, Spiegelman B, Kozak LP (1995) Expression of the mitochondrial uncoupling protein gene from the aP2 gene promoter prevents genetic obesity. J Clin Invest 96: 2914-2923

73. Baumruk F, Flachs P, Horakova M, Floryk D, Kopecky J (1999) Transgenic UCP1 in white adipocytes modulates mitochondrial membrane potential. FEBS Lett 444: 206-210

74. Li B, Nolte LA, Ju JS et al. (2000) Skeletal muscle respiratory uncoupling prevents diet-induced obesity and insulin resistance in mice. Nat Med 6: 1115-1120

75. Clapham JC, Arch JR, Chapman H et al. (2000) Mice overexpressing human uncoupling protein-3 in skeletal muscle are hyperphagic and lean. Nature 406: 415-418

76. Zhang CY, De-Leo D, Joseph J (2000) Uncoupling protein 2 negatively regulates insulin secretion. Molecular Endocrinology 14 [Suppl. 1]: 274-274 
77. Chan CB, MacDonald PE, Saleh MC, Johns DC, Marban E, Wheeler MB (1999) Overexpression of uncoupling protein 2 inhibits glucose-stimulated insulin secretion from rat islets. Diabetes 48: 1482-1486

78. Hong Y, Fink BD, Dillon JS, Sivitz WI (2001) Effects of adenoviral overexpression of uncoupling protein-2 and-3 on mitochondrial respiration in insulinoma cells. Endocrinology 142: 249-256

79. Wang MY, Shimabukuro M, Lee Y et al. (1999) Adenovirus-mediated overexpression of uncoupling protein-2 in pancreatic islets of Zucker diabetic rats increases oxidative activity and improves beta-cell function. Diabetes 48: $1020-1025$

80. Jezek P, Zackova M, Rehakova Z et al. (1999) Existence of uncoupling protein-2 antigen in isolated mitochondria from various tissues. FEBS Lett 455: 79-82

81. Pecqueur C, Alves-Guerra M-C, Gelly C et al. (2001) Uncoupling Protein 2 , in vivo distribution, induction upon oxidative stress, and evidence for translational regulation. J Biol Chem 276: 8705-8712

82. Cusin I, Zakrzewska KE, Boss O et al. (1998) Chronic central leptin infusion enhances insulin-stimulated glucose metabolism and favors the expression of uncoupling proteins. Diabetes 47: 1014-1019

83. Combatsiaris TP, Charron MJ (1999) Down regulation of uncoupling protein 2 mRNA in white adipose tissue and uncoupling protein $3 \mathrm{mRNA}$ in skeletal muscle during the early stages of leptin treatment. Diabetes 48: 128-133

84. Weigle DS, Selfridge LE, Schwartz MW et al. (1998) Elevated free fatty-acids induce uncoupling protein-3 expression in muscle - a potential explanation for the effect of fasting. Diabetes 47: 298-302

85. Millet L, Vidal H, Andreelli F et al. (1997) Increased uncoupling protein-2 and -3 mRNA expression during fasting in obese and lean humans. J Clin Invest 100: 2665-2670

86. Cortez-Pinto H, Yang SQ, Lin HZ et al. (1998) Bacterial lipopolysaccharide induces uncoupling protein-2 expression in hepatocytes by a tumor necrosis factor-alpha- dependent mechanism. Biochem Biophys Res Commun 251: 313-319

87. Lanni A, Beneduce L, Lombardi A et al. (1999) Expression of uncoupling protein-3 and mitochondrial activity in the transition from hypothyroid to hyperthyroid state in rat skeletal muscle. FEBS Lett 444: 250-254

88. Boss O, Bachman E, Vidal-Puig A, Zhang CY, Peroni O, Lowell BB (1999) Role of the beta(3)-adrenergic receptor and/or a putative beta(4)- adrenergic receptor on the expression of uncoupling proteins and peroxisome proliferator-activated receptor-gamma coactivator-1. Biochem Biophys Res Commun 261: 870-876

89. Aubert J, Champigny O, Saint-Marc P et al. (1997) Up regulation of UCP-2 gene expression by PPAR agonists in preadipose and adipose cells. Biochem Biophys Res Commun 238: 606-611

90. Kelly LJ, Vicario PP, Thompson GM et al. (1998) Peroxisome proliferator-activated receptors gamma and alpha mediate in vivo regulation of uncoupling protein (UCP-1, UCP- 2, UCP-3) gene expression. Endocrinology 139: 4920-4927

91. Camirand A, Marie V, Rabelo R, Silva JE (1998) Thiazolidinediones stimulate uncoupling protein-2 expression in cell lines representing white and brown adipose tissues and skeletal muscle. Endocrinology 139: $428-431$
92. Boivin M, Camirand A, Carli F, Hoffer LJ, Silva JE (2000) Uncoupling protein-2 and -3 messenger ribonucleic acids in adipose tissue and skeletal muscle of healthy males: variability, factors affecting expression, and relation to measures of metabolic rate. J Clin Endocrinol Metab 85: 1975-1983

93. Lin B, Coughlin S, Pilch PF (1998) Bidirectional regulation of uncoupling protein-3 and GLUT-4 mRNA in skeletal muscle by cold. Am J Physiol 275: E386-E391

94. Boss O, Samec S, Desplanches D et al. (1998) Effect of endurance training on mRNA expression of uncoupling proteins 1, 2, and 3 in the rat. FASEB J 12: 335-339

95. Schrauwen P, Troost FJ, Xia J, Ravussin E, Saris WHM (1999) Skeletal muscle UCP2 and UCP3 expression in trained and untrained male subjects. Int $\mathbf{J}$ Obes 23: 966-972

96. Matsuda J, Hosoda K, Itoh H et al. (1997) Cloning of rat uncoupling protein-3 and uncoupling protein-2 cDNAs: their gene expression in rats fed high-fat diet. FEBS Lett 418: 200-204

97. Boss O, Samec S, Kuhne F et al. (1998) Uncoupling protein-3 expression in rodent skeletal muscle is modulated by food intake but not by changes in environmental temperature. J Biol Chem 273: 5-8

98. Samec S, Seydoux J, Dulloo AG (1999) Post-starvation gene expression of skeletal muscle uncoupling protein 2 and uncoupling protein 3 in response to dietary fat levels and fatty acid composition - A link with insulin resistance. Diabetes 48: 436-441

99. Weindruch R, Walford RL, Fligiel S, Guthrie D (1986) The retardation of aging in mice by dietary restriction: longevity, cancer, immunity and lifetime energy intake. J Nutr 116: 641-654

100. Sheldon WG, Bucci TJ, Hart RW, Turturro A (1995) Age-related neoplasia in a lifetime study of ad libitum-fed and food-restricted b6c3f1 mice. Toxicol Pathol 23: 458-476

101. Oberkofler H, Dallinger G, Liu YM, Hell E, Krempler F, Patsch W (1997) Uncoupling protein gene: quantification of expression levels in adipose tissues of obese and nonobese humans. J Lipid Res 38: 2125-2133

102. Himms HJ, Melnyk A, Zingaretti MC, Ceresi E, Barbatelli G, Cinti S (2000) Multilocular fat cells in WAT of CL316243-treated rats derive directly from white adipocytes. Am J Physiol Cell Physiol 279: C670-C681

103. Bouillaud F, Villarroya F, Hentz E, Raimbault S, Cassard AM, Ricquier D (1988) Detection of brown adipose tissue uncoupling protein mRNA in adult patients by a human genomic probe. Clin Sci (Colch) 75: 21-27

104. Oberkofler H, Liu YM, Esterbauer H, Hell E, Krempler F, Patsch W (1998) Uncoupling protein-2 gene: reduced mRNA expression in intraperitoneal adipose tissue of obese humans. Diabetologia 41: 940-946

105. Nordfors L, Hoffstedt J, Nyberg B et al. (1998) Reduced gene expression of UCP2 but not UCP3 in skeletal muscle of human obese subjects. Diabetologia 41: 935-939

106. Simoneau JA, Kelley DE, Neverova M, Warden $\mathrm{CH}$ (1998) Overexpression of muscle uncoupling protein 2 content in human obesity associates with reduced skeletal muscle lipid utilization. FASEB J 12: 1739-1745

107. Vidal-Puig A, Rosenbaum M, Considine RC, Leibel RL, Dohm GL, Lowell BB (1999) Effects of obesity and stable weight reduction on $\mathrm{UCP} 2$ and $\mathrm{UCP} 3$ gene expression in humans. Obes Res 7: 133-140

108. Millet L, Vidal H, Larrouy D, Andreelli F, Laville M, Langin D (1998) mRNA expression of the long and short 
forms of uncoupling protein- 3 in obese and lean humans. Diabetologia 41: 829-832

109. Esterbauer H, Oberkofler H, Dallinger G et al. (1999) Uncoupling protein-3 gene expression: reduced skeletal muscle mRNA in obese humans during pronounced weight loss. Diabetologia 42: 302-309

110. Vidal H, Langin D, Andreelli F, Millet L, Larrouy D, Laville M (1999) Lack of skeletal muscle uncoupling protein 2 and 3 mRNA induction during fasting in type-2 diabetic subjects. Am J Physiol 277: E830-E837

111. Bao S, Kennedy A, Wojciechowski B, Wallace P, Ganaway E, Garvey WT (1998) Expression of mRNAs encoding uncoupling proteins in human skeletal muscle: effects of obesity and diabetes. Diabetes 47: 1935-1940

112. Krook A, Digby J, O'Rahilly S, Zierath JR, WallbergHenriksson H (1998) Uncoupling protein 3 is reduced in skeletal muscle of NIDDM patients. Diabetes 47: 1528-1531

113. Barbe P, Millet L, Larrouy D et al. (1998) Uncoupling protein-2 messenger ribonucleic acid expression during very-low-calorie diet in obese premenopausal women. J Clin Endocrinol Metab 83: 2450-2453

114. Pedersen SB, Borglum JD, Kristensen K et al. (2000) Regulation of uncoupling protein (UCP) 2 and 3 in adipose and muscle tissue by fasting and growth hormone treatment in obese humans. Int J Obes 24: 968-975

115. Pinkney JH, Boss O, Bray GA, Bulmer K, Coppack SW, Mohamed-Ali V (2000) Physiological relationships of uncoupling protein-2 gene expression in human adipose tissue in vivo. $\mathrm{J}$ Clin Endocrinol Metab 85: 2312-2317

116. Schrauwen P, Xia J, Bogardus C, Pratley RE, Ravussin E (1999) Skeletal muscle uncoupling protein 3 expression is a determinant of energy expenditure in Pima Indians. Diabetes 48: 146-149

117. Boss O, Bobbioni-Harsch E, Assimacopoulos-Jeannet F et al. (1998) Uncoupling protein-3 expression in skeletal muscle and free fatty acids in obesity letter. Lancet 351: 1933-1933

118. Paulik MA, Buckholz RG, Lancaster ME et al. (1998) Development of infrared imaging to measure thermogenesis in cell culture: thermogenic effects of uncoupling protein-2, troglitazone, and beta-adrenoceptor agonists. Pharm Res 15: 944-949

119. Yu XX, Mao W, Zhong A et al. (2000) Characterization of novel UCP5/BMCP1 isoforms and differential regulation of UCP4 and UCP5 expression through dietary or temperature manipulation. FASEB J 14: 1611-1618

120. Nagase I, Yoshida T, Kumamoto K et al. (1996) Expression of uncoupling protein in skeletal muscle and white fat of obese mice treated with thermogenic beta 3-adrenergic agonist. J Clin Invest 97: 2898-2904

121. Urhammer SA, Fridberg M, Sorensen TI et al. (1997) Studies of genetic variability of the uncoupling protein 1 gene in Caucasian subjects with juvenile-onset obesity. J Clin Endocrinol Metab 82: 4069-4074

122. Hamann A, Tafel J, Busing B et al. (1998) Analysis of the uncoupling protein-1 (UCP1) gene in obese and lean subjects: identification of four amino acid variants. Int $\mathbf{J}$ Obes Relat Metab Disord 22: 939-941

123. Oppert JM, Vohl MC, Chagnonl M et al. (1994) DNA polymorphism in the uncoupling protein (UCP) gene and human body fat. Int J Obes 18: 526-531

124. Gonzalez-Barroso MD, Pecqueur C, Gelly C et al. (2000) Transcriptional activation of the human ucp1 gene in a rodent cell line - Synergism of retinoids, isoprotere- nol, and thiazolidinedione is mediated by a multipartite response element. J Biol Chem 275: 3172231732

125. Clement K, Ruiz J, Cassard-Doulcier AM et al. (1996) Additive effect of $\mathrm{A}->\mathrm{G}(-3826)$ variant of the uncoupling protein gene and the Trp64Arg mutation of the beta 3-adrenergic receptor gene on weight gain in morbid obesity. Int $\mathbf{J}$ Obes Relat Metab Disord 20: 1062-1066

126. Hayakawa T, Nagai Y, Taniguchi M et al. (1999) Phenotypic characterization of the beta3-adrenergic receptor mutation and the uncoupling protein 1 polymorphism in Japanese men. Metabolism 48: 636-640

127. Esterbauer H, Oberkofler H, Liu YM et al. (1998) Uncoupling protein-1 mRNA expression in obese human subjects: the role of sequence variations at the uncoupling protein-1 gene locus. J Lipid Res 39: 834-844

128. Fumeron F, Durackbown I, Betoulle D et al. (1996) Polymorphisms of uncoupling protein (ucp) and beta-3 adrenoceptor genes in obese people submitted to a lowcalorie diet. Int J Obes 20: 1051-1054

129. Fogelholm M, Valve R, Kukkonen-Harjula K et al. (1998) Additive effects of the mutations in the beta3-adrenergic receptor and uncoupling protein-1 genes on weight loss and weight maintenance in Finnish women. J Clin Endocrinol Metab 83: 4246-4250

130. Urhammer SA, Hansen T, Borch-Johnsen K, Pedersen O (2000) Studies of the synergistic effect of the Trp/ $\operatorname{Arg}(64)$ polymorphism of the beta(3)-adrenergic receptor gene and the- $3826 \mathrm{~A}->\mathrm{G}$ variant of the uncoupling protein-1 gene on features of obesity and insulin resistance in a population- based sample of 379 young Danish subjects. J Clin Endocrinol Metab 85: 3151-3154

131. Evans D, Minouchehr S, Hagemann G et al. (2000) Frequency of and interaction between polymorphisms in the beta 3-adrenergic receptor and in uncoupling proteins 1 and 2 and obesity in Germans. Int J Obes 24: 1239-1245

132. Valve R, Heikkinen S, Rissanen A, Laakso M, Uusitupa M (1998) Synergistic effect of polymorphisms in uncoupling protein-1 and beta(3)-adrenergic receptor genes on basal metabolic-rate in obese Finns. Diabetologia 41: 357-361

133. Sivenius K, Valve R, Lindi V, Niskanen L, Laakso M, Uusitupa M (2000) Synergistic effect of polymorphisms in uncoupling protein 1 and beta3-adrenergic receptor genes on long-term body weight change in Finnish type 2 diabetic and non-diabetic control subjects. Int J Obes Relat Metab Disord 24: 514-519

134. Allison DB, Heo M, Faith MS, Pietrobelli A (1998) Meta-analysis of the association of the Trp64Arg polymorphism in the beta3 adrenergic receptor with body mass index. Int $\mathbf{J}$ Obes Relat Metab Disord 22: 559-566

135. Kimura K, Sasaki N, Asano A et al. (2000) Mutated human beta 3-adrenergic receptor (Trp64Arg) lowers the response to beta 3-adrenergic agonists in transfected 3T3-L1 preadipocytes. Horm Metab Res 32: 91-96

136. Surwit RS, Wang S, Petro AE et al. (1998) Diet-induced changes in uncoupling proteins in obesity-prone and obesity-resistant strains of mice. Proc Natl Acad Sci U S A 95: 4061-4065

137. Warden CH, Fisler JS, Pace MJ, Svenson KL, Lusis AJ (1993) Coincidence of genetic-loci for plasma-cholesterol levels and obesity in a multifactorial mouse model. J Clin Invest 92: 773-779 
138. Taylor BA, Phillips SJ (1996) Detection of obesity qtls on mouse chromosome-1 and chromosome-7 by selective dna pooling. Genomics 34: 389-398

139. Taylor BA, Tarantino LM, Phillips SJ (1999) Gender-influenced obesity QTLs identified in a cross involving the KK type II diabetes-prone mouse strain. Mamm Genome 10: 963-968

140. York B, Truett AA, Monteiro MP et al. (1999) Gene-environment interaction: a significant diet-dependent obesity locus demonstrated in a congenic segment on mouse chromosome 7. Mamm Genome 10: 457-462

141. Kaisaki PJ, Woon PY, Wallis RH, Monaco AP, Lathrop M, Gauguier D (1998) Localization of tub and uncoupling proteins (Ucp) 2 and 3 to a region of rat Chromosome 1 linked to glucose intolerance and adiposity in the GotoKakizaki (GK) Type 2 diabetic rat. Mamm Genome 9: 910-912

142. Gauguier D, Froguel P, Parent V et al. (1996) Chromosomal mapping of genetic-loci associated with noninsulin-dependent diabetes in the gk rat. Nat Genet 12: $38-43$

143. Hanson RL, Ehm MG, Pettitt DJ et al. (1998) An autosomal genomic scan for loci linked to type II diabetes mellitus and body-mass index in Pima Indians. Am J Hum Genet 63: 1130-1138

144. Norman RA, Tataranni PA, Pratley R et al. (1998) Autosomal genomic scan for loci linked to obesity and energy metabolism in Pima Indians. Am J Hum Genet 62: 659-668

145. Norman RA, Thompson DB, Foroud T et al. (1997) Genomewide search for genes influencing percent body fat in Pima Indians: suggestive linkage at chromosome 11q21-q22. Pima Diabetes Gene Group. Am J Hum Genet 60: 166-173

146. Hager J, Dina C, Francke S et al. (1998) A genome-wide scan for human obesity genes reveals a major susceptibility locus on chromosome 10. Nat Genet 20: 304-308

147. Lee JH, Reed DR, Li WD et al. (1999) Genome scan for human obesity and linkage to markers in 20q13. Am J Hum Genet 64: 196-209

148. Bouchard C, Perusse L, Chagnon YC, Warden C, Ricquier D (1997) Linkage between markers in the vicinity of the uncoupling protein 2 gene and resting metabolic rate in humans. Hum Mol Genet 6: 1887-1889

149. Watanabe RM, Ghosh S, Langefeld CD et al. (2000) The Finland-United States Investigation of Non-InsulinDependent Diabetes Mellitus Genetics (FUSION) study. II. An autosomal genome scan for diabetes-related quantitative-trait loci. Am J Hum Genet 67: 1186-1200

150. Ghosh S, Watanabe RM, Valle TT et al. (2000) The Finland-United States Investigation of Non-Insulin- Dependent Diabetes Mellitus Genetics (FUSION) study. I. An autosomal genome scan for genes that predispose to type 2 diabetes. Am J Hum Genet 67: 1174-1185

151. Elbein SC, Leppert M, Hasstedt S (1997) Uncoupling protein 2 region on chromosome $11 \mathrm{q} 13$ is not linked to markers of obesity in familial type 2 diabetes. Diabetes 46 : 2105-2107

152. Comuzzie AG, Almasy L, Cole SA et al. (2000) Linkage exclusion analysis of the chromosome 11 region containing UCP2 and UCP3 with obesity-related phenotypes in Mexican Americans. Int J Obes 24: 1065-1068

153. Walder K, Norman RA, Hanson RL et al. (1998) Association between uncoupling protein polymorphisms (UCP2UCP3) and energy metabolism/obesity in Pima indians. Hum Mol Genet 7: 1431-1435
154. Cassell PG, Neverova M, Janmohamed S et al. (1999) An uncoupling protein 2 gene variant is associated with a raised body mass index but not Type II diabetes. Diabetologia 42: 688-692

155. Yanovski JA, Diament AL, Sovik KN et al. (2000) Associations between uncoupling protein 2 , body composition, and resting energy expenditure in lean and obese African American, white, and Asian children. Am J Clin Nutr 71: 1405-1420

156. Astrup A, Toubro S, Dalgaard LT, Urhammer SA, Sorensen TI, Pedersen O (1999) Impact of the v/v 55 polymorphism of the uncoupling protein 2 gene on 24-h energy expenditure and substrate oxidation. Int J Obes Relat Metab Disord 23: 1030-1034

157. Urhammer SA, Dalgaard LT, Sorensen TI et al. (1997) Mutational analysis of the coding region of the uncoupling protein 2 gene in obese NIDDM patients: impact of a common amino acid polymorphism on juvenile and maturity onset forms of obesity and insulin resistance. Diabetologia 40: 1227-1230

158. Dalgaard LT, Sorensen TI, Andersen T, Hansen T, Pedersen O (1999) An untranslated insertion variant in the uncoupling protein 2 gene is not related to body mass index and changes in body weight during a 26-year follow-up in Danish Caucasian men. Diabetologia 42: 1413-1416

159. Kubota T, Mori H, Tamori Y et al. (1998) Molecular screening of uncoupling protein 2 gene in patients with noninsulin-dependent diabetes mellitus or obesity. J Clin Endocrinol Metab 83: 2800-2804

160. Klannemark M, Orho M, Groop L (1998) No relationship between identified variants in the uncoupling protein-2 gene and energy-expenditure. Eur J Endocrinol 139: 217-223

161. Tu N, Chen H, Winnikes U et al. (1998) Structural organization and mutational analysis of the human uncoupling protein-2 (hUCP2) gene. Life Sci 64: L41-L50

162. Otabe S, Clement K, Rich N et al. (1998) Mutation screening of the human UCP 2 gene in normoglycemic and NIDDM morbidly obese patients: Lack of association between new UCP 2 polymorphisms and obesity in French Caucasians. Diabetes 47: 840-842

163. Shiinoki T, Suehiro T, Ikeda Y et al. (1999) Screening for variants of the uncoupling protein 2 gene in Japanese patients with non-insulin-dependent diabetes mellitus. metabolism 48: 581-584

164. Chung WK, Luke A, Cooper RS et al. (1999) Genetic and physiologic analysis of the role of uncoupling protein 3 in human energy homeostasis. Diabetes 48: 1890-1895

165. Argyropoulos G, Brown AM, Willi SM et al. (1998) Effects of mutations in the human uncoupling protein 3 gene on the respiratory quotient and fat oxidation in severe obesity and type 2 diabetes. J Clin Invest 102: $1345-1351$

166. Otabe S, Clement K, Dubois S et al. (1999) Mutation screening and association studies of the human uncoupling protein 3 gene in normoglycemic and diabetic morbidly obese patients. Diabetes 48: 206-208

167. Brown AM, Willi SM, Argyropoulos G, Garvey WT (1999) A novel missense mutation, R70 W, in the human uncoupling protein 3 gene in a family with type 2 diabetes. Human Mutation 13: 506-506

168. Brown AM, Dolan JW, Willi SM, Garvey WT, Argyropoulos G (1999) Endogenous mutations in human uncoupling protein 3 alter its functional properties. FEBS Lett 464: 189-193 
169. Solanes G, Pedraza N, Iglesias R, Giralt M, Villarroya F (2000) The human uncoupling protein-3 gene promoter requires MyoD and is induced by retinoic acid in muscle cells. FASEB J 14: 2141-2143

170. Schrauwen P, Xia J, Walder K, Snitker S, Ravussin E (1999) A novel polymorphism in the proximal UCP3 promoter region: effect on skeletal muscle UCP3 mRNA expression and obesity in male nondiabetic Pima Indians. Int J Obes 23: 1242-1245

171. Otabe S, Clement K, Dina C et al. (2000) A genetic variation in the 5' flanking region of the UCP3 gene is associated with body mass index in humans in interaction with physical activity. Diabetologia 43: 245-249

172. Meirhaeghe A, Amouyel P, Helbecque N et al. (2000) An uncoupling protein 3 gene polymorphism associated with a lower risk of developing Type II diabetes and with atherogenic lipid profile in a French cohort. Diabetologia 43: $1424-1428$
173. Cassell PG, Saker PJ, Huxtable SJ et al. (2000) Evidence that single nucleotide polymorphism in the uncoupling protein 3 (UCP3) gene influences fat distribution in women of European and Asian origin. Diabetologia 43: 1558-1564

174. Dalgaard LT, Sørensen TIA, Drivsholm T et al. (2001) $A$ prevalent polymorphism in the promoter of the UCP3 gene and its relationship to body mass index and long term body weight change in the Danish population. J. Clin. Endocrinol Metab 86: 1398-1402

175. Zhang C-Y, Baffy G, Perret P et al. (2001) Uncoupling protein-2 negatively regulates insulin secretion and is a major link between obesity, $\beta$-cell dysfunction, and Type 2 diabetes. Cell 105: 745-755

176. Esterbauer H, Schneitler C, Oberkofler H et al (2001) A common polymorphism in the promoter of $U C P 2$ is associated with decreased risk of obesity in middle-aged humans. Nat Genet 28: 178-183 